Georgia State University

ScholarWorks @ Georgia State University

$2-2018$

\title{
Political settlements, women's representation and gender equality: The 2008 gender-based violence law and gender parity in primary and secondary education in Rwanda
}

Jennie E. Burnet

Georgia State University, jburnet@gsu.edu

Jeanne d'Arc Kanakuze

jeannecap@yahoo.fr

Follow this and additional works at: https://scholarworks.gsu.edu/anthro_facpub

Part of the Anthropology Commons

\section{Recommended Citation}

Burnet, J. E. and Kanakuze, J. d'A. (2018) Political settlements, women's representation and gender equality: The 2008 gender-based violence law and gender parity in primary and secondary education in Rwanda. ESID Working Paper No. 94. Manchester, UK: The University of Manchester. Available at www.effective-states.org.

This Article is brought to you for free and open access by the Department of Anthropology at ScholarWorks @ Georgia State University. It has been accepted for inclusion in Anthropology Faculty Publications by an authorized administrator of ScholarWorks @ Georgia State University. For more information, please contact scholarworks@gsu.edu. 
Political settlements, women's representation and gender equality: The 2008 gender-based violence law and gender parity in primary and secondary education in Rwanda

Jennie E. Burnet ${ }^{1}$ and Jeanne d'Arc Kanakuze ${ }^{2}$

February, 2018

${ }^{1}$ Global Studies Institute, Georgia State University, Atlanta, USA

Email correspondence: iburnet@gsu.edu

${ }^{1}$ Independent consultant, Kigali Rwanda

Email correspondence: jeannecap@yahoo.fr

ISBN: 978-1-908749-96-3 


\begin{abstract}
This paper explores the ways in which power and politics shape the realisation of women's rights and gender equity in Rwanda. In the past decade, Rwanda has become a global leader in increasing women's inclusion in politics and in promoting and securing women's rights. This paper considers legislative reform, policy formulation and policy implementation in two areas: gender-based violence and gender parity in education. The paper injects a gender analysis into the political settlement theoretical framework and seeks to answer two questions: (1) how do women and other actors (including formal and information institutions, powerbrokers and other key decision-makers) negotiate within Rwanda's dominant-party form of political settlement? And (2) how does Rwanda's political settlement shape gender equity policy outcomes?

This study found that Rwanda's success in terms of women's rights is the result of its vibrant women's movement, the political will of the dominant party, the expertise of professional technocrats in the government administration, and a system of performance contracts, which shapes bureaucratic behaviour through to the frontline of service delivery. These findings are significant because they highlight the importance of a highly qualified, professional cadre in government and of accountability within government administration for securing women's rights.
\end{abstract}

Keywords: Rwanda, political settlement, gender analysis, gender-based violence, education, gender equity, universal primary education, Millennium Development Goals (MDGs)

Burnet, J. E. and Kanakuze, J. d'A. (2018) Political settlements, women's representation and gender equality: The 2008 gender-based violence law and gender parity in primary and secondary education in Rwanda. ESID Working Paper No. 94. Manchester, UK: The University of Manchester. Available at www.effective-states.org

\footnotetext{
The background research for this paper was funded by the Effective States and Inclusive Development Research Centre (ESID), based at The University of Manchester, UK. This document is an output from a project funded by UK Aid from the UK government for the benefit of developing countries. However, the views expressed and information contained in it are not necessarily those of, or endorsed by the UK government, which can accept no responsibility for such views or information or for any reliance placed on them.
} 


\begin{tabular}{|c|c|}
\hline Acronym & Definition \\
\hline AEE & African Evangelistic Enterprise \\
\hline CEDAW & $\begin{array}{l}\text { Convention on the Elimination of All Forms of Discrimination Against } \\
\text { Women }\end{array}$ \\
\hline COMESA & Common Market for Eastern and Southern Africa \\
\hline CSO & Civil society organisation \\
\hline DFID & Department for International Development \\
\hline DR-Congo & Democratic Republic of the Congo \\
\hline EDPRS & Economic Development and Poverty Reduction Strategy \\
\hline EDPRS I & Economic Development and Poverty Reduction Strategy I \\
\hline ESID & Effective States and Inclusive Development \\
\hline FAWE & Forum for African Women Educators \\
\hline FAWE- & Forum for African Women Educators, Rwanda Chapter \\
\hline \multicolumn{2}{|l|}{ Rwanda } \\
\hline FWP & Forum for Women Parliamentarians \\
\hline GBV & Gender-based violence \\
\hline GDP & Gross domestic product \\
\hline GPE & Global Partnership for Education \\
\hline HIVIAIDS & $\begin{array}{l}\text { Human immunodeficiency virus infection and acquired immune } \\
\text { deficiency syndrome }\end{array}$ \\
\hline ICGLR-SGBV & $\begin{array}{l}\text { International Conference of the Great Lakes Region on Sexual } \\
\text { Gender-based Violence }\end{array}$ \\
\hline ICT & Information communication technology \\
\hline ICTR & International Criminal Tribunal for Rwanda \\
\hline MAJ & Maisons d'accès à la justice \\
\hline MCC & Millennium Challenge Corporation \\
\hline MDGs & Millennium Development Goals \\
\hline MDR & Mouvement démocratique républicain \\
\hline MIGEFASO & Ministry of Gender, Family and Social Affairs \\
\hline MIGEPROF & Ministry of Gender and Family Promotion \\
\hline MINEDUC & Ministry of Education \\
\hline MP & Member of parliament \\
\hline MRND & $\begin{array}{l}\text { Mouvement républicain national pour la démocratie et le } \\
\text { développement }\end{array}$ \\
\hline NEPAD & New Partnership for Africa's Development \\
\hline NGO & Non-governmental organisation \\
\hline PACFA & Protection and Care of Families against HIVIAIDS \\
\hline PDC & Parti Démocrate Centrist (formerly Parti Démocrate Chrétien) \\
\hline PDI & Parti Démocratique Idéale (formerly Parti Démocratique Islamique) \\
\hline PDR & Party for Democracy and Renewal \\
\hline PL & Liberal Party \\
\hline PPC & Parti pour le progrès et la concorde \\
\hline PS-Imberakuri & Parti socialiste-Imberakuri \\
\hline PSD & Parti Social Démocrate \\
\hline PSR & Parti Socialiste Rwandais \\
\hline
\end{tabular}


Political settlements, women's representation and gender equality: The 2008 gender-based violence law and gender parity in primary and secondary education in Rwanda

$\begin{array}{ll}\text { RPF } & \text { Rwandan Patriotic Front } \\ \text { RWAMREC } & \text { Rwanda Men's Resource Centre } \\ \text { TNP } & \text { Transitional National Parliament } \\ \text { UN } & \text { United Nations } \\ \text { UNAMIR } & \text { United Nations Assistance Mission to Rwanda } \\ \text { UNESCO } & \text { United Nations Educational, Scientific and Cultural Organisation } \\ \text { UNFPA } & \text { United Nations Population Fund } \\ \text { UNICEF } & \text { United Nations Children's Fund } \\ \text { USAID } & \text { United States Agency for International Development } \\ \text { YWCA- } & \text { Young Women's Christian Association of Rwanda }\end{array}$

Rwanda 


\section{Introduction}

In the past decade, Rwanda has become one of the global leaders in terms of expanding women's inclusion in politics and promoting and securing women's rights. In 2008, only 14 years after the 1994 genocide against the Tutsis, Rwandans elected a female majority to the national legislature that nearly reached gender parity. Women realised this achievement thanks in large part to a gender quota system that encompassed all levels and branches of the government. The gender quotas were created with the adoption of a new constitution in 2003. Its preamble declared a national commitment to gender equality, 'committed to ensuring equal rights between Rwandans and between women and men without prejudice to the principles of gender equality and complementarity in national development' (clause 10). Article 9 of the constitution guaranteed that 'women are granted at least thirty per cent of posts in decision making organs' of the entire government. ${ }^{1}$

The gender quotas are not the only reason Rwanda has become a global leader in promoting women's rights, however. Four significant pieces of legislation that enhanced women's rights were passed before the gender quotas were put in place: the 1996 law on genocide; ${ }^{2}$ the 1999 'inheritance law, ${ }^{3}$ which allowed women and girls to own and inherit property; the 2001 children's rights law, ${ }^{4}$ and the 2003 constitution, which created the gender quotas. Since implementation of gender quotas in 2003, fewer policies improving women's status have passed, but there have been some successes. The 2004 land policy and accompanying 2005 land law clarified women's property rights under the 1999 inheritance law, including their rights to own and inherit real estate. This policy helped alleviate gender-based class inequities in terms of land ownership (Carpano, 2011; Simons and Schulze, 2011).

Scholars have attributed Rwanda's success in enhancing and protecting women's rights and increasing women's representation to numerous factors, including the Rwandan Patriotic Front's (RPF) long-term commitment to mainstreaming women, Rwanda's vibrant women's civil society organisations (CSOs), the use of behind-thescenes lobbying of male allies to convince them to support policy initiatives and laws, and a transformation in the international development context whereby aid agencies have mainstreamed women and gender approaches (Newbury and Baldwin, 2001; Longman, 2006; Powley, 2005; Devlin and Elgie, 2008; Powley and Pearson, 2007; Burnet, 2008; Burnet, 2011; Coffe, 2012). These studies all focused on legislative initiatives to expand women's rights, but did not fully consider implementation as a relevant variable for evaluating their effectiveness.

\footnotetext{
${ }^{1}$ Article 76 established reserved women's seats in the Chamber of Deputies (the parliament's lower house) and article 82 established that 'at least thirty per cent' of the Senate shall be women, without establishing a precise mechanism for arriving at this outcome.

${ }^{2}$ Organic Law No. 08/96 of 30 August 1996 on the Organization of Prosecutions for Offences constituting the Crime of Genocide or Crimes against Humanity Committed since October 1 , 1990.

${ }^{3}$ Law No 22/99 of 12 November 1999 to Supplement Book I of the Civil Code and to Institute Part Five Regarding Matrimonial Regimes, Liberalities and Successions.

${ }^{4}$ Law No 27/2001 Relating to the Rights and Protection of the Child Against Violence.
} 
In this paper, we explore the extent of women's inclusion and participation in formal political institutions and informal processes and the women's movement's ability to negotiate gender equity concerns in terms of legislative reform and policy formulation in two areas: gender parity in education and gender-based violence (GBV). The research sought to answer two specific questions: (1) how do women and other state or non-state actors (including formal and information institutions, powerbrokers, and other key decision-makers) negotiate within given political settlements? And (2) how do different types of political settlements shape differences in gender equity outcomes in specific policy areas of gender parity in education and GBV? By 'political settlement', this project refers to a growing body of theory within development studies that conceptualises political stability and development in post-conflict states as resulting from a combination of formal political processes and institutions and informal negotiations and 'distribution of power between contending social groups and social classes, on which any state is based' (Di John and Putzel, 2009: 4).

Political settlement is a theoretical framework for understanding the ways power is organised and exercised in developing countries and post-conflict societies. The concept has taken hold in development studies since the UK Department for International Development (DFID) formally incorporated the political settlement theoretical framework into its institutional mission in 2010. ${ }^{5}$ Fritz and Menocal (2007: 27) define political settlement as a 'negotiated agreement (at least in principle) binding together state and society and providing the necessary legitimacy for those who govern over those who are ruled'. In other words, political settlements define the 'distribution of organizational and political power between competing groups and classes' (Khan, 2004: 168).

The political settlement framework offers several advantages in terms of analysing how power is distributed in non-democratic states. Unlike approaches grounded in new institutionalism that emphasise the building of institutions for good governance (see, for example, Acemoglu, Johnson and Robinson, 2001; or North, 1990), the political settlement framework foregrounds informal institutions, which can include political coalitions that cross party lines, elite bargains based on personal ties instead of impersonal organisations (North et al., 2009), and patronage (Khan, 2010). The political settlement framework shows how these informal institutions emerge and why they dominate in ways that undermine the rules associated with formal institutions.

The current literature and theories on political settlement are underdeveloped and largely blind to gender. ${ }^{6}$ As Nazneen and Mahmud (2012) pointed out, there are significant gaps in understanding how the informal and clientelistic forms of politics meaning the exchange of goods or services for political support - shape prospects for women's political empowerment. The feminist literature on women in politics and gender mainstreaming has largely focused on the formal institutions and processes, leaving out the impact of clientelism and patronage-based politics on women as

\footnotetext{
${ }^{5}$ When DFID adopted its Building Peaceful States and Societies Practice Paper.

${ }^{6}$ See North, Wallis, Weingast (2009); or Khan (2010).
} 
[political] actors and on gender equity outcomes. Nazneen and Mahmud (2012) and Nazneen (2012) indicate that the character and dynamics of political settlement, as well as the discourses about women's political entitlements and gender equity, shape the relationship between women's political inclusion and their ability to deliver gender-inclusive development.

This paper aims to begin to fill this gap by engaging with the conceptual framework of political settlements to understand two primary things: first of all, to understand the ways in which Rwanda's dominant-party form of political settlement shapes the institutional arrangements and ideas that govern the pursuit, adoption, implementation and outcomes of gender equity policies. Specifically, we compare the adoption and implementation of two gender equity policies: anti-GBV legislation and gender equity in primary and secondary education. These policy cases were selected collectively by researchers working on all four countries included in this project (Bangladesh, Ghana, Rwanda and Uganda). In this investigation of informal political power, we emphasise the ways in which key actors and formal and informal institutions interact with each other, the ways that in which power is wielded in a dominant type political settlement, and the ways these structural formations and power relations affect gender equity outcomes. Secondly, we want to illuminate gender as a relevant variable in the political settlements theoretical framework and contribute to the elaboration of theory around political settlements as it relates to gender. From this analysis, we conclude that Rwanda's success in terms of women's rights rests not only on top-down political will and a vibrant women's movement, but also on the professional technocrats ${ }^{7}$ in the government administration, and the system of performance contracts, which shapes bureaucratic behaviour through to the frontline of service delivery. This conclusion is significant because it highlights the importance of a highly qualified, professional cadre in government and of accountability within government administration.

This research was conducted as part of a larger project that compared the impact of political settlements on women's inclusion in politics and gender equity in policymaking in four developing countries: Bangladesh, Ghana, Rwanda and Uganda. ${ }^{8}$ In Rwanda, the Young Women's Christian Association of Rwanda (YWCA-Rwanda) sponsored the research by providing feedback on the research plan, inviting potential interviewees to participate, locating policy documents and laws for the desk review, organising a research restitution workshop for stakeholders, and compiling feedback from stakeholders on the draft report. The Ministry of Gender and Family Promotion (MIGEPROF) sponsored the application for a research permit. The research protocol was reviewed and approved by the Rwandan National Research Ethics Committee.

\footnotetext{
${ }^{7}$ Throughout this paper, the term 'technocrat,' is used to refer to professionals working in the government with specific, high-level educational training of technical expertise in economics, public policy, public health, public administration, etc. Use of the term 'technocrat' emphasises an approach to government administration as a technical problem to be solved with the use of science, engineering or best practices.

${ }^{8}$ The project was funded by the UK's DFID as part of its policy-research initiative, the Effective States and Inclusive Development Research Centre (ESID) at the University of Manchester (United Kingdom).
} 
The Ministry of Education reviewed the project to ensure compliance with Rwandan research policies and provided the necessary research authorisation. ${ }^{9}$

Qualitative research methods were used in this project, including: review of relevant scholarly literature; Rwandan government reports, studies, policy documents, and legislation; and international and non-governmental organisation (NGO) reports and documents. Semi-structured key informant interviews were conducted with a strategic sample of 35 state and non-state actors, including pro-women coalitions, male allies within the state, women's representatives, actors within the women's movement, and representatives of formal and informal institutions involved in promoting gender equality in Rwanda. The interviewees included 25 women and 10 men, representatives from the ministries, legislators and elected officials, the national police, civil society organisations (CSOs), international NGOs or the United Nations (UN), educators, and private citizens with specific knowledge of the policies in question (see Annex 1 for a summary of the interviewee characteristics). Interviews were usually conducted in Kinyarwanda, but sometimes in French or English, depending on the preference of the interviewee. ${ }^{10}$

To analyse the data, the team first developed a timeline matrix depicting significant events, critical junctures and key gender reforms. This information was drawn from published sources, key documents and interview transcripts. Then, the team mapped key actors involved in achieving gender parity in education and creating legislation and policy on GBV. Key actors were identified through review of the scholarly literature and news reports, interviews with key informants, and the authors' long experience in and knowledge of Rwanda. Third, key documents on the selected policy areas and the data from the semi-structured interviews were systematically analysed for content and discourse based on a set of relevant themes developed in collaboration with the research teams from the other country cases (see Annex 3 for a list of documents examined).

Below we first trace the evolution of Rwanda's current political settlement and women's historical exclusion from, and then gradual inclusion in, the political settlement. Then, we present our findings from analysis of the adoption and implementation policy case 1, the 2008 law on Prevention and Punishment of Gender-based Violence followed by the analysis of policy case 2, gender parity in primary and secondary education. In the conclusion, we reflect on these findings and

\footnotetext{
${ }^{9}$ Research permit \# MINEDUC/S\&T/259/2014.

${ }^{10}$ All interviews were conducted by Jeanne d'Arc Kanakuze. An interview guide (see Annex 2) helped ensure consistency in the topics covered and questions asked. Beyond the desk review and interviews, the authors drew on their long-term engagement with women's CSOs and the study of gender in Rwanda. Jeanne d'Arc Kanakuze has been involved with Rwandan CSOs since she was a young girl in the Girl Guides. She has served in leadership positions in CSOs in Rwanda and internationally, and she has worked as a researcher, evaluator of gender programmes around the world. Jennie Burnet has conducted several years of ethnographic research in Rwanda and published widely on gender issues and women's cSOs.
} 
outline important outcomes of adding a gender analysis to the political settlement framework.

\section{Women's inclusion in politics and policymaking in Rwanda}

\section{Critical junctures in Rwanda's political settlement (1950-94)}

To understand Rwanda's current political settlement, it is important to understand critical junctures since the end of colonialism. The decolonisation process in Rwanda (1952-61) polarised divisions that had emerged during the colonial period. The Belgian colonial administration had concentrated power in the hands of Tutsi chiefs, while excluding Hutu from administrative positions and the education system. As a result, two political conflicts emerged: (1) Hutu and Tutsi nationalist elites ${ }^{11}$ jointly pursued the end of Belgian colonial rule and its replacement with self-rule; and (2) Hutu nationalists pursued emancipation for the Hutu majority, from Belgian rule and what they claimed was Tutsi colonialism (Golooba-Mutebi, 2013: 4). In November 1959, pro-independence demonstrations shifted into attacks against Tutsi political elites and their families: several hundred Tutsis were killed, a few thousand homes were burned, and approximately 10,000 (predominantly Tutsi) refugees left the country (Reyntjens, 1985: 261). Belgium developed a hasty decolonisation plan that called for a transition to a participatory democracy with multiple political parties. Although a few political parties attempted to appeal to voters across ethnic lines, the largest parties mobilised along ethnic lines. The 1961 legislative elections confirmed the ethnic cleavage, with Hutu-dominated parties winning the majority of seats. By the end of the transition in 1963, Rwanda had a democratically elected Hutu president, Grégoire Kayibanda, who was from southern Rwanda. During the decolonisation process, women and women's issues never emerged on the national scene.

In 1989, several political parties, which had been dormant under the single-party state and dictatorship of President Habyarimana, re-emerged and began demanding political liberalisation. Along with a few CSOs that were also pushing for change, their pleas coincided with increasing pressure in the international community for authoritarian states to democratise. In many cases, this pressure tied political reforms to international aid, a particularly sensitive issue for the Rwandan government, as the country was dependent on foreign aid. The CSO movement was consolidated in September 1990 with the publication of a memorandum, 'For multiparty politics and democracy'.

\footnotetext{
${ }^{11}$ The term 'elites' is used throughout this working paper to refer to Rwandans who have high levels of educational attainment, wealth, political power and social status within Rwandan society. These elites may or may not hold political office or wield official power. Regardless, they exercise considerable influence and informal power.
} 
Table 1. Women in Rwandan parliament (1961-94)

\begin{tabular}{|cccc}
\hline \multicolumn{4}{c|}{ National parliament } \\
\hline Year & Total seats & Women (\#) & Women (\%) \\
\hline 1961 & 44 & 0 & $0 \%$ \\
\hline 1965 & 47 & 1 & $2.1 \%$ \\
\hline 1969 & 47 & 0 & $0 \%$ \\
\hline 1982 & 64 & 4 & $6.3 \%$ \\
\hline 1983 & 70 & 9 & $12.9 \%$ \\
\hline 1988 & 70 & 11 & $15.7 \%$ \\
\hline 1994 & 70 & 8 & $11.4 \%$ \\
\hline & \multicolumn{3}{c}{ Source: Burnet, 2008: 370.} \\
\hline
\end{tabular}

Although the political liberalisation movement was dominated by men, women were not completely absent. The Mouvement Républicain National pour la Démocratie et le Dévelopement (MRND), the state political party, had created a women's wing, called the Urama, in 1988. Agathe Kanziga Habyarimana, wife of President Habyarimana, brokered a great deal of power behind the scenes in the Habyarimana regime, as she hailed from a powerful family from Northern Rwanda. Many of her male kin occupied important positions in the Habyarimana government and Rwandan military. The other political parties that re-emerged in the early 1990s also created women's wings. Among the national leaders of the Mouvement Démocratique Républicain (MDR) party was Agathe Uwilingiyimana, who was named Minister of Education in 1992 and then Prime Minister of Rwanda in 1993. Uwilingiyimana was killed on the 7 April 1994 along with her husband and the ten Belgian soldiers who were guarding her as part of the UN peacekeeping mission to Rwanda, United Nations Assistance Mission to Rwanda (UNAMIR). Other women ministers in the early 1990s included Agnes Ntamabyaliro (Minister of Commerce, Industry, Mines and Artisans 1992-93, and Minister of Justice 1993-94) and Pauline Nyiramasuhuko (Minister of Women and Family 1992-94). Nyiramasuhuko was among the leaders of the Interahamwe during the genocide and was the first woman found guilty of genocide and using rape as a weapon of genocide by the International Criminal Tribunal for Rwanda (ICTR) in 2011. Beyond women in government, a number of women's CSOs were founded in the 1980s, as discussed in detail below.

On 1 October 1990, the country entered a war when the RPF invaded with intention to liberate Rwanda from President Habyarimana's dictatorship. ${ }^{12}$ The liberation war had a significant influence over the political transition. The war continued throughout the early 1990s until Habyarimana, facing dramatic losses as well as continued pressure from donors, was forced to the negotiating table. The 1993 Arusha Peace

\footnotetext{
${ }^{12}$ Organised in Uganda in the late 1980s, the RPF recruited in the exile community in Uganda, Burundi, Democratic Republic of the Congo (then Zaire), Tanzania and elsewhere in the diaspora. It also collaborated with internal opponents of Habyarimana's regime (GoloobaMutebi 2013: 8).
} 
Accords brought an official end to hostilities and outlined a transition plan to move the country to multiparty politics and democratic elections.

The transition came to a dramatic and violent halt in April 1994, when President Habyarimana's plane was shot down as it was landing at the Kigali International Airport. Immediately, Hutu extremists took control of the government and perpetrated a genocide against the Tutsis and killed others defined as 'enemies' of the state. The genocide resulted in the deaths of 1 million Tutsis, according to the Rwandan government census of genocide victims (MINALOC, 2004). The genocide also included mass rape, sexual torture and sexual enslavement of women and girls; the theft or destruction of Tutsis' private property, livestock, homes and businesses; and the near complete destruction of the country's infrastructure. At the same time, the RPF resumed its liberation war against the government army, which was also involved in the genocide. The genocide ended when the RPF took military control of the majority of the territory, driving the Hutu-extremist government, militias and army into exile. The fleeing government forces encouraged, and sometimes forced, approximately over 2 million civilians to go with them. ${ }^{13}$ While some scholars may argue that the 1993 Arusha Peace Accords constituted a negotiated settlement type, we reject this proposition, because the accords were essentially set aside until the RPF liberated the country.

\section{Critical junctures in Rwanda's political settlement (1994-present)}

According to Levy (2012), political settlements are either characterised primarily by 'dominant parties' or by 'competitive clientelism'. In this typology, Rwanda's current political settlement comprises the dominant party type (Golooba-Mutebi 2013). The critical juncture of the current political settlement was the 1994 genocide against the Tutsis and its aftermath, whereby the RPF became the dominant party in a governance system characterised by regular elections with limited competition between political parties (Golooba-Mutebi 2013: 12, 18; Booth and Golooba-Mutebi, 2012). On 19 July 1994, the RPF named a transitional government, which it called the 'Government of National Unity', whose composition reaffirmed the RPF's commitment to power sharing outlined in the Arusha Accords. The RPF announced that the transitional government would remain in power for five years. The transitional government named by the RPF and six other political parties in the power-sharing agreement (i.e., MDR, Liberal Party [PL], Parti Social Démocrate [PSD], Parti Démocratique Idéale [formerly Parti Démocratique Islamique] (PDI), Parti Démocrate Centrist [formerly Parti Démocrate Chrétien] [PDC), and Parti Socialiste Rwandais [PSR)) was the first national government to include a significant number of women. The first Transitional National Parliament (TNP) appointed in 1994, included ten women, including three of the 13 RPF deputies. Between 1994 and 2003, members of the TNP were appointed by the Forum of Political Organizations (a consultative forum for political parties) after being nominated by the political parties included in

\footnotetext{
${ }^{13}$ The official UNHCR count of Rwandan refugees in other countries in 1994 was 2.257 million, while the Government of Rwanda estimated over 3 million. See UNHCR Historical Refugee Data visualisation at http://data.unhcr.org/datavizl (accessed 27 February 2014).
} 
the government. Over time, the number of women in parliament increased (see Table 1). By 1999 over one-quarter of parliamentarians were women and before parliamentary elections in 2003, women held 25.7 percent of seats in parliament.

In 1999, the parliament extended the transition by four years, in order to implement the transition programme as outlined in the 1993 Arusha Accords, including the drafting of the new constitution (International Crisis Group, 2002: 1). Competitive elections were gradually introduced during the extension of the transition, beginning with district-level elections in 2001. The same year, a Constitutional Commission was appointed. In 2003, the new constitution was approved by national referendum in May and promulgated on 4 June. Presidential elections were then held in August and parliamentary elections in September. President Paul Kagame stood for election, along with two other candidates who ran as independents: Faustin Twagiramungu, a former prime minister and former head of the MDR political party, who returned to Rwanda from Belgium to stand; and Jean-Nepomuscene Nayinzira (Samset and Dalby, 2003: 20-21). RPF candidate, President Paul Kagame won 95 percent of the vote, Twagiramungu 3.7 percent, and Jean-Nepomuscene Nayinzira 1.3 percent. In the parliamentary elections, the RPF and parties in its coalition won 96 percent of the seats in the lower house.

\section{Women's inclusion, policy-making, and the current political settlement}

A key aspect of Rwanda's post-genocide political settlement has been a top-tobottom effort to transform gender relations, increase representation of women in every branch and level of government, and increase protection of women's rights.

\section{Women's inclusion in governance}

Among the fundamental principles articulated in the 2003 constitution (article 9) was 'the equality of all Rwandans and between women and men reflected by ensuring that women are granted at least thirty percent of posts in decision making organs'. The constitution remained mute on the mechanisms for ensuring this gender quota; however, it did delineate reserved women's seats in the Chamber of Deputies, the lower house of parliament. Since the first parliamentary elections under the new constitution were held in 2003, women have made remarkable gains in their representation in the Rwandan parliament. In every election, women captured seats well beyond the 24 reserved women's seats in the Chamber of Deputies. In the 2013 elections, women candidates were very well represented among the candidates on all party lists and comprised for 48 percent of candidates on the RPF-coalition of candidates.

Despite the constitution's clear instructions for representation of women throughout the government, the goal of at least 30 percent women in all decision-making organs has not yet been reached in all government bodies. While there is no clear explanation for the slower pace of integrating women in these areas, lack of eligible candidates and lack of interest among women candidates (for local government, police and military) were the most often mentioned reasons. Table 3 summarises women's representation in various parts of the government as of September 2015. 
Women's representation in the highest levels of the executive branch and the judiciary exceeds the quota, whereas the provincial and district levels of the local governments have not yet reached 30 percent.

Table 2. Women in Rwandan parliament after gender quota (2003-13)

\begin{tabular}{|cccc|cccc|}
\hline \multicolumn{4}{|c|}{ Chamber of Deputies } & \multicolumn{4}{c|}{ Senate } \\
\hline Year & Seats & Women & \%W & Year & Seats & Women & $\% W$ \\
2003 & 80 & 39 & $48.8 \%$ & 2003 & 26 & 9 & $34.6 \%$ \\
2008 & 80 & 45 & $56.3 \%$ & 2011 & 26 & 10 & $38.5 \%$ \\
2013 & 80 & 51 & $63.7 \%$ & 2013 & 26 & 9 & $34.6 \%$ \\
\hline \multicolumn{4}{|c|}{ Source: Burnet, 2008: 370} & and parliamentary website. \\
\hline
\end{tabular}

In terms of other aspects of inclusion, the key actors in Rwanda's ruling coalition, including the RPF-ruling party and President Paul Kagame, have advocated for greater representation of women. President Kagame and key ministry officials have 'repeatedly articulated strong support for women's role in government and society' (Longman, 2006: 141). In a 2008 speech before the UN General Assembly, the president said,

'With regards to empowering women and promoting their socio economic and political participation, we continue to make modest progress. We believe that, besides improving gender relations in our country, this marks healthy progress towards realizing our vision of a united, democratic and prosperous Rwanda. ${ }^{14}$

Based on the speeches published on his website, President Kagame has regularly spoken on gender, women's rights and the importance of equal opportunities for girls and women as cornerstones to the nation's development. ${ }^{15}$

As far as we have been able to document, none of the registered political parties in Rwanda requires gender quotas in their party lists. However, the National Consultative Forum of Political Organizations, a constitutionally mandated coordinating entity, issued instructions in 2013 to parties to alternate male and female candidates on their lists. The RPF-Inkotanyi political party maintains a women's league and includes party members on the women's councils at every level of government down to the village (umudugudu) in its party structure. The constitution of the party does not require any gender quotas, such as alternating

\footnotetext{
${ }^{14}$ Cited in Republic of Rwanda 2010.

15 'Speeches', President Paul Kagame's website, http://paulkagame.com/?page_id=1273 (accessed 7 November 2017). See, for example, speeches in 2015: http://paulkagame.com/?p=3932 (accessed 7 November 2017); 2013: http://paulkagame.com/?p=2415 $\quad$ (accessed $\quad 7 \quad$ November 2017 ), http://paulkagame.com/?p=206 (accessed 7 November 2017); and 2009: http://paulkagame.com/?p=42 (accessed 7 November 2015).
} 
male and female candidates, for party lists in parliamentary elections. ${ }^{16}$ Nonetheless, in the 2013 parliamentary elections, the RPF candidate list, which included candidates from the other parties in its coalition, began with a female candidate and largely alternated female and male candidates. ${ }^{17}$ Of the three opposition parties who presented independent candidate lists for the 2013 parliamentary elections, two parties, Parti Socialiste-Imberakuri (PS-Imberakuri) and PL put women candidates at the head of the list. ${ }^{18}$ As Dahlerup (2005: 150) has noted, the gender of the candidate at the head of party lists can play a decisive role in the gender outcome of parliamentary elections in multi-party, first-past-the-post electoral systems.

Table 3. Women's representation in state apparatus (September 2013 and 2015)

\begin{tabular}{|c|c|c|c|c|c|c|}
\hline & \multirow{2}{*}{ Government Body } & \multirow{2}{*}{ Total } & \multicolumn{2}{|c|}{ Male } & \multicolumn{2}{|c|}{ Female } \\
\hline & & & 2013 & 2015 & 2013 & 2015 \\
\hline \multirow{3}{*}{ Cabinet } & Ministers & 20 & $12(65 \%)$ & $11(60 \%)$ & $8(35 \%)$ & $9(40 \%)$ \\
\hline & State ministers & 8 & $5(62.5 \%)$ & $(52.5 \%)$ & $3(37.5 \%)$ & $(47.5 \%)$ \\
\hline & $\begin{array}{l}\text { Permanent } \\
\text { secretaries }\end{array}$ & 19 & $12(63 \%)$ & $(50 \%)$ & $7(37 \%)$ & $(50 \%)$ \\
\hline \multirow{2}{*}{$\begin{array}{l}\text { Local } \\
\text { Government }\end{array}$} & $\begin{array}{l}\text { Governors } \\
\text { (provinces) }\end{array}$ & 5 & $4(80 \%)$ & $3(60 \%)$ & $1(20 \%)$ & $2(40 \%)$ \\
\hline & Mayors (districts) & 30 & $27(90 \%)$ & $27(90 \%)$ & $3(10 \%)$ & $3(10 \%)$ \\
\hline \multirow{2}{*}{ Parliament } & $\begin{array}{l}\text { Chamber of } \\
\text { Deputies }\end{array}$ & 80 & $\begin{array}{r}29 \\
(36.3 \%)\end{array}$ & $\begin{array}{r}29 \\
(36.3 \%)\end{array}$ & $\begin{array}{r}51 \\
(63.7 \%)\end{array}$ & $\begin{array}{r}51 \\
(63.7 \%)\end{array}$ \\
\hline & Senate & 26 & $\begin{array}{r}17 \\
(65.4 \%) \\
\end{array}$ & $\begin{array}{r}16 \\
(61.5 \%) \\
\end{array}$ & $9(34.6 \%)$ & $\begin{array}{r}10 \\
(38.5 \%) \\
\end{array}$ \\
\hline \multirow{3}{*}{ Judiciary } & Supreme Court & 14 & $8(47.1 \%)$ & $7(50 \%)$ & $6(42.9 \%)$ & $7(50 \%)$ \\
\hline & $\begin{array}{l}\text { High commercial } \\
\text { courts }\end{array}$ & 7 & $4(57 \%)$ & $4(57 \%)$ & $3(43 \%)$ & $3(43 \%)$ \\
\hline & Intermediate courts & 99 & $\begin{array}{r}60 \\
(60.6 \%)\end{array}$ & $\begin{array}{r}60 \\
(60.6 \%) \\
\end{array}$ & $\begin{array}{r}39 \\
(39.4 \%) \\
\end{array}$ & $\begin{array}{r}39 \\
(39.4 \%) \\
\end{array}$ \\
\hline
\end{tabular}

Source: Data collected in Rwanda.

Women hold influential positions in the major political parties, including the RPF, its coalition parties and opposition parties. Within the RPF, historically influential women leaders have included Rose Kabuye and the late Aloysie Inyumba, who passed away in 2012. In the PL, Dr Odette Nyiramilimo has served as secretary general of the party since 2001 and held several important positions in the government, including minister of state for social affairs, senator, and currently Rwandan parliamentarian to the East African Legislative Assembly. Jaqueline Muhongayire, a PSD member, was the vice speaker of the transition parliament in 1994 and later a member of the East Africa Legislative Assembly.

\footnotetext{
16 'RPF Constitution', RPF-Inkotanyi website, available at http://rpfinkotanyi.org/wp/?page id=97 (accessed 3 February 2014).

${ }_{17}$ 'NEC releases preliminary MP candidates list', Great Lakes Voice website, available at http://greatlakesvoice.com/nec-releases-preliminary-mp-candidates-list/ (accessed 3 February 2014).

${ }^{18}$ Ibid.
} 
Women's CSOs and leaders of the women's movement in Rwanda were vital to the inclusion of gender quotas in the 2003 constitution. Beginning shortly after the genocide, women's CSOs rose to prominence in Rwanda, lobbying on behalf of women's rights and their special needs in the aftermath of the genocide. Whereas some scholars have noted the absence of effective CSOs in Rwanda (Gready, 2010; Longman, 1997; 2011), women's CSOs in the late 1990s and early 2000s largely operated with more freedom than many other CSOs. During this period, women's CSOs were perceived as organisations focused on development and not politics and thus given more space to operate and advocate (Burnet 2008). The women's movement had several significant successes before gender quotas came into effect: (1) the inclusion of rape and sexual violence as among the most serious genocide crimes in the 1995 genocide statute; and (2) the 1998 amendment to the civil code giving women and girls greater financial autonomy in marriage and the right to inherit property. In this way, women's CSOs influenced the outcomes of the current political settlement.

After the creation of the gender quotas in all decision-making bodies in government, many women's CSO leaders took positions in the government and the majority joined the RPF political party. Women were motivated to join the RPF because they had seen the party's policy of promoting women's rights. Furthermore, other parties had ignored women in the past. For example, following the publication of Réseau des Femmes' report on the need to include women in decision-making bodies, the PSD party president rebuked women, saying that they should go create their own political party if they wanted to be involved in the government. ${ }^{19}$ Eventually, other parties joined the RPF in promoting women when they saw the RPF's success recruiting women members. Once other parties began placing women high on their party lists during elections, they also began to attract more women members. Thus, the current political settlement has simultaneously been influenced by women, but also increased the role of women in the ruling coalition.

Within the Rwandan state, the gender machinery, which expanded gradually after the genocide and then rapidly in the first decade of the 21st century, and femocrats (i.e., feminist bureaucrats, both female and male) have played a significant role in influencing gender equitable outcomes. In late 1994, the transitional government created the Ministry of Gender, Family, and Social Affairs (MIGEFASO), the first government ministry dedicated to gender issues. The ministry was reorganised in 1999 and renamed 'the Ministry of Gender and Family Promotion' (MIGEPROF). Technocrats and gender specialists within the ministry were key in collaborating with the Forum of Women Parliamentarians (FWPs) to develop the 1999 inheritance law. By the early 2000s, femocrats comprising not only women but also men with explicit gender training or who had bought into the gender agenda, had become a critical mass. Femocrats within MIGEPROF again served as resources during the drafting of the 2008 GBV law and conducted a national grassroots consultation as the law was being revised. The state gender machinery continued to expand throughout the early

\footnotetext{
${ }^{19}$ Interview with women's civil society leader via telephone by Burnet, 10 January 2015.
} 
2000s, with the creation of the Gender Monitoring Office and mandates for all budgets within all state entities to include gender mainstreaming.

\section{Enhancing women's rights through policy-making}

Rwanda has a long track record of signing and ratifying international human rights instruments. The country ratified the Universal Declaration of Human Rights (UDHR), the UN International Covenant on Civil and Political Rights (ICCPR), the UN International Convention on the Elimination of All Forms of Racial Discrimination, the UN Convention on the Elimination of All Forms of Discrimination against Women (CEDAW), the UN Convention on the Political Rights of Women, the UN Convention on the Rights of the Child, and the Protocol to the African Charter on the Rights of Women in Africa (a.k.a. the Maputo Protocol), among others. However, the vast majority of nations have signed and ratified the very same international instruments without dramatically increasing women's rights. As discussed in detail below, the influence and impact of the international human rights instruments is far more complicated than the simple adoption of laws and standards from outside. At opportune moments, leaders within the Rwandan women's movement leveraged these external mechanisms to justify and support internal changes.

Feminist scholars, such as Htun and Weldon (2010) have distinguished between policies that are either transformative or ameliorative in terms of gendered ideas and power relations (cited in Nazneen 2012, p. 3). Htun and Weldon (2010) explain that ameliorative policies 'improve the status of women as a group and alleviate gender based class inequities', while transformative ones 'challenge dominant views and norms on gender equity, as often expressed in religion or traditions based on culture' (Nazneen, 2012: 3fn5). Htun and Weldon's typology is not always neatly applicable, since many policy initiatives are simultaneously ameliorative and transformative. In Rwanda, three significant pieces of legislation helped revolutionise gender norms in Rwandan society: the 1995 genocide code ${ }^{20}$ the 1999 inheritance law, ${ }^{21}$ and the 2003 constitution. Under Htun and Weldon's (2010) typology, the first can be classified as ameliorative, the second as transformative, and the third as ameliorative in intent and transformative in outcome. Several other pieces of legislation, such as the 2001 children's rights bill, were ameliorative.

In the aftermath of the genocide, women's CSOs along with the FWP quickly began to advocate on women's issues. Much of this advocacy emerged out of necessity: Rwandans in general, and Rwandan women in particular, faced circumstances they had never before encountered. According to a Rwandan government tally, over 1 million Tutsi were killed in the genocide (MINALOC 2004: 21). ${ }^{22}$ Genocide survivors

\footnotetext{
${ }^{20}$ Organic Law No. 08/96 of 30 August 1996 on the Organisation of Prosecution of Offences. ${ }^{21}$ 12/11/1999 Law N ${ }^{\circ} 22 / 99$ to Supplement Book I of the Civil Code and to Institute Part Five Regarding Matrimonial Regimes, Liberalities and Successions. O.G. N²2 OF 15/11/1999.

${ }^{22}$ This figure comes from the 2004 census of genocide victims undertaken by the Ministry of Local Government. The study identified 1,074,017 genocide victims who had been killed (MINALOC 2004: 21). In the study, genocide victim was defined according to Law 08/96 as 'every person who was killed between 1 October 1990 and 31 December 1994 because he
} 
were psychologically and physically traumatised and among them were thousands of women and girls who had been sexually assaulted, raped, sexually enslaved and sexually mutilated. In addition, millions of Rwandans who did not participate in the genocide had been eyewitnesses to killings and other terrible events that took place during the genocide.

The government needed to craft a legal statute on genocide to prosecute those accused of planning, organising or participating in the genocide. In 1995, the Ministry of Justice drafted a genocide statute to prosecute the tens of thousands of Rwandans detained on suspicion of genocide crimes. The government's statute classified genocide crimes into four categories, with the worst crimes of leading, organising and planning the genocide in Category 1, killing in Category 2, physical assault not resulting in death in Category 3 , and property crimes in Category 4 (articles 2-3 of Organic Law No. 08/96). The original statute did not specifically address rape, sexual torture or sexual enslavement. It elicited a strong and unexpected reaction from rural women living in Taba commune. A long-time leader in the women's civil society movement recounted:

'It was the morning [when they announced on the radio that the draft genocide code placed rapists in the Category 4, the lowest level genocide crimes] that a group of women raped during the genocide came to see me. They said, "They have treated us like toys, like property. Go quickly to see your women from Réseaux des femmes œuvrant pour le développement rural". I went to Kigali to see Veneranda Nzambazamariya, who was a big activist back then. I told her everything and asked her what we should do. She called the journalist, Immaculee Ingabire. They went together to see the women parliamentarians; there were only 12 of them then.

'They all came to Taba where the raped women explained everything to this group of activists and women parliamentarians. How they had been raped during the genocide, how terrible it was to be raped by ten men. Radio Rwanda was there'. ${ }^{23}$

In the months following, the women parliamentarians lobbied their male colleagues for changes to the law, while women civil society leaders and journalists raised awareness about the issue. This internal movement was then joined by an international coalition of feminist human rights lawyers. Collectively they advocated for rape to be added to Category 1 genocide crimes in the national statute and for the

was Tutsi or looked Tutsi, had family ties with a Tutsi, was the friend of or had particular relationships with a Tutsi, he had political thoughts or relationships to people with political thoughts that opposed the extremist politics from before 1994' (cited in MINALOC 2004: 17, authors' translation of original French). Original French: 'toute personne qui a été tuée pendant la période du 1/10/1990 au 31/12/1994 parce qu'elle est tutsi ou lui ressemble, a des liens de parenté avec un tutsi, est son amie ou a des affinités particulières avec lui, elle a des pensées politiques ou est apparenté aux personnes ayant des pensées politiques contraires à celles de l'idéologie de politique divisionniste d'avant 1994' (MINALOC 2004: 17).

${ }^{23}$ Interview with executive secretary, women's CSO, September 2014. 
ICTR prosecutor's office to include sexual crimes among genocide crimes and crimes against humanity. These initial efforts between 1994 and 1997 framed most claims in terms of women's rights and crimes targeting women and girls. By 1997, the discourses shifted from 'women' to 'gender', when the Ministry of Women's Affairs became the Ministry of Gender and Family Affairs ${ }^{24}$ (Powley and Pearson, 2007: 18).

Women's CSOs took up another important gender issue in the aftermath of genocide: inheritance law and property ownership in marriage. According to Rwandan custom, women relied on men for access to the means of livelihood (Burnet and RISD, 2003: 187; Human Rights Watch, 1996: 19). After the genocide, women took on new roles in the domestic and public spheres that Rwandan society had previously not ascribed to them. Many Rwandan women took on primary economic responsibility for their households because their husbands were either absent or unable to do it (Burnet, 2008: 384). Before the genocide, Rwandan law had forbidden Rwandan women from engaging in commercial activities, entering into contracts, or seeking paid employment without authorisation from their husbands (Human Rights Watch, 1996: 22). In practice, many husbands (and even most husbands in the cities) allowed and even encouraged their wives to work, but husbands often controlled women's salaries or profits from commercial endeavours (Jefremovas, 2002: 97-108).

In the aftermath of the genocide, women-headed and child-headed households suddenly grew exponentially (Burnet, 2012: 65-66). Because Rwandan law limited women's property rights and excluded women and girls from inheritance, either as spouses or children, these households were extremely vulnerable to having their property expropriated by others, especially by male kin. In response to this situation, women's CSOs, the MIGEPROF, and the FWP, worked closely together in formulating policy, crafting a new law, and lobbying decision-makers in other ministries and within the inner circle of the RPF to pass the controversial bill. The legislation, commonly referred to as 'the inheritance law', ${ }^{25}$ amended the civil code to create three matrimonial property regimes and to change the default inheritance structure to divide property among all siblings, including women and girls, instead of only among male siblings. ${ }^{26}$ The law also gave women full legal rights to enter into contracts, seek paid employment, own property in their own names and separately from their husbands, and open bank accounts without the authorisation of their husbands or fathers. Passed by the National Assembly in November 1999, the law dramatically reconfigured customary inheritance practices and gave girl children equal rights with boy children in matters of inheritance. Burnet (2008: 376-378) details the collaboration of women activists in CSOs, femocrats in the ministries, and women in the legislature, who used both ideological and pragmatic appeals to

\footnotetext{
${ }^{24}$ The Ministry of Gender and Family Affairs was later renamed the Ministry of Gender and Family Promotion (MIGEPROF).

${ }^{25}$ Law No 22/99 of 12/11/99 to Supplement Book I of the Civil Code and to Institute Part Five Regarding Matrimonial Regimes, Liberalities and Successions.

${ }^{26}$ Republic of Rwanda, 'Law to Supplement Book One of the Civil Code and to Institute Part Five Regarding Matrimonial Regimes, Liberalities and Successions', Official Gazette of the Republic of Rwanda 38(22) (1999).
} 
convince key leaders in the RPF political party, along with key men in opposition parties, that the law was a good idea. Similar legislation failed in neighbouring Uganda (Kawamara-Mishambi and Ovonji-Odida, 2003).

The 2001 children's rights bill ${ }^{27}$ was primarily ameliorative, in that it extended certain rights to children and guaranteed equal rights to male and female children. Although the title of the law highlighted protection against violence, the far-ranging law delineated children's rights to know their parents; to have shelter, food, and clothing; and to safety. In addition, the law expanded children's rights to be adopted. Political elites, including government ministers, technocrats advising the cabinet, and influential members of the RPF party, made gender equality and equity a national priority when they included a commitment 'continuously update and adapt its laws on gender' as a cross-cutting pillar of its Rwanda Vision 2020 Strategic Plan, which was adopted in 2000 (Republic of Rwanda 2000: 21).

Another important institution was the Constitutional Commission that drafted the new constitution adopted in 2003 and, in particular, Judith Kanakuze, one of the three female members of 12-member commission (Mageza-Barthel 2015: 108). It was Ms. Kanakuze who first suggested including reserved women's seats in the parliament and who eventually added the government-wide women's quota of 30 percent. While male members of the commission at first reacted sceptically to the idea, they eventually bought into it as well. Some men objected to what they perceived as 'special' rights for women. One of the RPF founders, Tito Rutaremara, ${ }^{28}$ was one of the first men among the commissioners to be persuaded by the idea and support it. ${ }^{29}$ Interviewees were not able to give detailed information about the arguments used to persuade members to adopt the gender quota, other than the principle that a country coming out of genocide should be inclusive in its development and, in particular, inclusive of women. In the ongoing governance of Rwanda, the Gender Monitoring Office is another key actor that performs both a policing/monitoring role for women's inclusion and helps set policy for the various government institutions. The 2003 constitution comprised ameliorative and transformative policy simultaneously. On the one hand, it alleviated gender-based class inequities by creating a government-wide gender quota of 30 percent and instituting reserved women's seats in the lower house of parliament. On the other hand, it codified into law women/wives and men/husbands equality, whereas cultural and religious notions had long placed women under male authority in Rwanda.

Numerous key actors within the Rwandan political landscape are behind women's inclusion in the governance of Rwanda. Many of these key actors are discussed at length above, including women's CSOs, such as Pro-Femmes Twese Hamwe,

\footnotetext{
${ }^{27}$ Law 27/01 Relating to the Rights and Protection of the Child Against Violence.

${ }^{28}$ Rutaremara has also served as secretary general of the RPF, chairman of the Forum of Political Organisations, president of the constitutional commission, and Ombudsman of Rwanda (Mageza-Barthel 2015: 108).

${ }_{29}$ Interview by Kanakuze, Kigali, Rwanda, 2015. Personal communication to Burnet, Kigali, Rwanda, 2007.
} 
Haguruka, Réseau des femmes, Duterimbere and many others, women's CSO leaders, the FWPs, femocrats through the government and especially in MIGEPROF, the leaders of the RPF political party, and President Paul Kagame. At its founding, the RPF created a department for women, Urugaga rw'abagore (Women's Network), to promote women and their participation.

'They continued to empower women, then after the genocide against the Tutsi, [the party] met the activists in the civil society who had the expertise to analyse the gender aspect. The RPF and civil society were key actors to women empowerment. ${ }^{30}$

In Rwanda, women's issues have been framed in a gradually changing way in the public sphere since 1994. In the first several years after the genocide, gender issues and protecting women's rights were framed as a social necessity. Because the 1994 genocide created a new context for gender relations, Rwandan law and society had to change to accommodate the new status quo. Over time, women's issues came to be framed as morally just, the so-called 'modern' way to do things, and as beneficial to the entire culture. According to one long-time activist in women's CSOs, a key reason why gender equality took off after the 1994 genocide and creation of the Government of National Unity was the changed ideology of the RPF. ${ }^{31}$ Before the genocide, the government said that it was committed to women's rights, but it allowed patriarchal ideas to dominate. For example, men would say that the purpose of gender equity was to 'force men to weed gardens'. ${ }^{32}$ Finally, as the gender quotas took hold and Rwanda became recognised as a world leader on gender issues, promoting women's rights became a point of national pride. Rwandans today are proud and will tell you that 'Rwanda is first in gender'. In the beginning of this gender revolution, advocates for women's rights often used a different tack behind closed doors or in the private sphere. These women often couched their advocacy to male audiences in terms of family-oriented, 'motherist' politics by appealing to the men's sense of justice for their own mothers' and daughters' rights. ${ }^{33}$

\section{Policy case 1: The 2008 gender-based violence law}

The 2008 gender-based violence law ${ }^{34}$ was a ground-breaking piece of legislation on numerous fronts. First of all, the legislation directly challenged deeply entrenched cultural notions that subjugated women's rights in Rwanda by outlawing domestic violence ${ }^{35}$ defining non-consensual marital sex as rape $^{36}$ and a punishable crime, ${ }^{37}$

\footnotetext{
${ }^{30}$ Interview with consultant and expert on gender, December 2014.

${ }^{31}$ Interview with women's civil society activist, December 2014.

${ }^{32}$ Interview with women's civil society activist, December 2014.

33 Interviews by Burnet, 1998 and 2000.

${ }^{34}$ Law No. 59/2008 of 2008 on Prevention and Punishment of Gender-based Violence.

${ }^{35}$ Article 2, clause 1 defines gender-based violence and specifies that includes violence within households, 'gender-based violence: any act that results in a bodily, psychological, sexual and economic harm to somebody just because they are female or male. Such act results in the deprivation of freedom and negative consequences. This violence may be exercised within or outside households'.
} 
and making polygamy, which was already illegal, punishable by law. ${ }^{38}$ Second, it was the first piece of legislation that was initiated by the legislative branch, rather than in the executive. Almost all legislation before, and most legislation since, originated in the executive branch, where technocrats in the ministries or consultants crafted initial drafts of laws that were then amended and adopted by the legislature (Coffe, 2012: 289). Third, it has been vigorously implemented and has transformed numerous institutions in Rwanda, from the National Police to the creation of GBV one-stop centres that address GBV survivors' needs holistically, whether legal, economic, physical or emotional. Finally, it was one of the first comprehensive laws criminalising all forms of GBV passed in Sub-Saharan Africa. According to Htun and Weldon's (2010) typology of gender-specific policy reforms, anti-GBV legislation can be understood as a transformative policy that transformed fundamental notions of gender and challenged status quo interests of predominantly male powerbrokers within the political settlement. The 2008 gender-based violence law certainly fits within this framework, as it redefined numerous fundamental cultural notions about gender relations in the home, family and society in Rwanda.

After the efforts in 1995 to amend the genocide code and place rape and sexual torture among Category 1 crimes, the issue of sexual violence faded from everyday discussion. It again rose to prominence beginning in 2001 when numerous cases of child rape had made it into the news. These stories horrified and shocked people and raised awareness about sexual violence as a contemporary problem. Although not yet labelled 'GBV', these instances of sexual violence against minors initiated a public discussion of sexual violence. Interviewees said that GBV became an important issue between 2003 and 2005. During this period, MIGEPROF conducted a study on GBV that was published in 2004 and that established the severity of the problem (Powley and Pearson, 2007: 20). Then, in 2005 a national conference on GBV was held in Kigali (Powley and Pearson, 2007: 19). As explained in more detail below, a small group of parliamentarians, mostly but not exclusively female, drafted the bill after the conference. In early 2006, the GBV bill was first introduced into parliament, but it was not adopted until 2008, due to a long grassroots consultative process and numerous revisions. At the time, some observers feared that the consultative process was being used to delay the bill, while others saw it as necessary to achieve national buy-in to the law and improve the text, so that it would bear up under scrutiny by the courts (Powley and Pearson, 2007).

\footnotetext{
${ }^{36}$ Article 5, 'Both spouses enjoy equal rights in terms of sexual intercourse, reproductive health and family planning. It is forbidden to have sexual intercourse without the spouse's consent' (author's translation of French article, original language in which the law was written).

${ }^{37}$ Article 19, 'Any person who coerces his/her spouse to sexual intercourse shall be liable to imprisonment of six (6) months to two (2) years'.

${ }^{38}$ Article 22, 'Any person guilty of getting married while there still exists a valid marriage contract between him/her and someone else shall be liable to imprisonment of three (3) years to five (5) years and a fine between three hundred thousand (300,000RwF) Rwandan francs and five hundred thousand (500,000 RwF) Rwandan francs'.
} 


\section{Actors, institutions, incentives and interests}

The key actors and institutions centrally involved in drafting, revising and advocating for the law included women's CSOs unified under Pro-Femmes Twese Hamwe, the umbrella organisation for women's CSOs, the FWP, MIGEPROF, and Judith Kanakuze, an MP who had emerged from women's CSOs and who had a keen feminist desire to enhance women's rights. During the implementation phase, key actors and institutions grew to also include the National Police, the judiciary, the Ministry of Health, the Ministry of Local Governance, and local government officials.

The issue of GBV initially came to prominence through the work of women's CSOs. Haguruka, a legal aid society for women, received many victims of domestic violence and child sexual abuse who were seeking legal assistance. ${ }^{39}$ Other CSOs encountered instances of GBV in their fieldwork. As a result of this knowledge, women activists began to advocate for a law on that issue. Women's CSOs' activities in support of the GBV bill focused on awareness-raising activities, advocacy, research, and monitoring and evaluation (UNFPA, n.d.: 21). Haguruka played an important role in terms of legal expertise and advocacy. ${ }^{40}$ These activities helped provide women MPs with the information they needed to advocate for the GBV bill and provided forums for advocacy around GBV through informal channels.

Interviewees disagreed over whether it was women's CSOs or MIGEPROF who first presented the issue to the parliament. ${ }^{41}$ In practice, there has been a great deal of overlap in the membership of women's CSOs, MIGEPROF staff and women parliamentarians. Many of the first women parliamentarians came directly from women's CSOs or MIGEPROF to take their seats. Almost all interviewees mentioned the coalition between CSOs and MPs who were aware of gender issues. ${ }^{42}$ Although they had resigned their CSO positions, they remained in close contact with their former colleagues. In essence, whether in the parliament, in the ministries or executive branch, or in CSOs, there was a strong sense of unity within the Rwandan women's movement.

Virtually all interviewees named MP Judith Kanakuze and the FWP as instrumental in drafting and lobbying to pass the GBV law. Kanakuze was an MP who had risen to political prominence through her lifetime engagement with women's CSOs. Before joining the constitutional commission, she had served for several years as executive secretary of Duterimbere, a women's credit union modelled after the Grameen Bank. In drafting the GBV law, Kanakuze was joined by seven other MPs, including a man, Aimable Niyibishaka, who was an outstanding leader on gender issues. According to

\footnotetext{
${ }^{39}$ Interview with representative, National Women's Council, September 2014.

${ }^{40}$ Interview with representative, National Women's Council, September, 2014.

${ }^{41}$ Interview with representative, Rwanda Men's Resource Centre, September 2014; interview with senior officer, National Police, February 2015.

${ }^{42}$ Interview with representative, Rwanda Men's Resource Centre, September 2014; interview with representative, National Women's Council, September 2014; interview with executive secretary, Women's CSO, September 2014; interview with senior officer, National Police, February 2015.
} 
one women's CSO leader, the FWP contracted a consultant to write the first draft of the bill, but the initial text was not accepted, so Kanakuze took the leading role to revise the draft. ${ }^{43}$

Once the law had been presented in parliament, MIGEPROF played a big role in raising the awareness of other MPs and advocated for passing it. ${ }^{44}$ MIGEPROF led a national grassroots consultation process to present the draft bill to citizens throughout the country and receive feedback. The consultation process was used because parliamentarians were worried that people might reject certain aspects of the law, such as criminalising marital rape. During the consultation process, however, they encountered few objections and instead heard people calling for much more severe punishments than those proposed in the draft law. The main objections came over the conjugal rape clauses, as some men insisted that rape in marriage is impossible, since spouses give consent when they marry. In public outreach about the GBV law, 'women parliamentarians were also careful to engage men as fathers and sons, not as husbands' (Powley and Pearson, 2007: 19). One male parliamentarian involved in the grassroots consultation process reflected on his experience,

'I was in charge of delivering this particular message [on gender-sensitivity]. At the end of the meetings, local leaders, local male leaders, were shaken up. Hearing the message from a man was an added value, [they were] more convinced, more able, to take the message seriously. But if the message had come from a woman you [would have] found them saying, "Oh, yes we know the story," but they [wouldn't have] given it much weight. They tend to be more concerned with gender issues when a man delivers the message' (cited in Powley and Pearson, 2007: 19).

Thus, the FWP and their allies defused widespread opposition to the new law.

Throughout the process, the RPF supported the bill. The RPF has long been the champion of women's rights and gender equality. The most powerful key actors promoting the GBV law were either members of the RPF or members of parties within the RPF coalition. For example, Aloysie Inyumba, who was senator at the time the law was passed, and a founding member of the RPF, offered leadership on the GBV issue, sought partner funding for studies, the grassroots consultation process, and elaboration of the GBV policy. ${ }^{45}$ President Paul Kagame supported the reforms. ${ }^{46}$ Tito Rutaremara supported the gender quota in the constitution; his support did not disappear after the elections although his influence became informal. ${ }^{47}$

\footnotetext{
${ }^{43}$ Interview with representative, National Women's Council, September 2014.

${ }^{44}$ Interview with senior officer, National Police, February 2015.

${ }^{45}$ Interview with executive secretary, Women's CSO, September 2014.

${ }^{46}$ Interview with director, Roman Catholic secondary school, September 2014.

${ }^{47}$ Interview with director, Roman Catholic secondary school, September 2014.
} 
Donors played a role in preparing the way for the GBV law by supporting women's CSOs who were active on GBV issues and by conducting research to establish the facts required to make a case for the GBV bill. UN-Women provided technical support throughout the legislative and implementation processes. In 2006 the Women's Legal Rights Initiative Rwanda and Chemonics International conducted a GBV programming study. In 2008, MIGEPROF and United Nations Population Fund (UNFPA) conducted a GBV mapping exercise to prepare the way for implementation of the GBV law. In 2010, UN Women hired a consultant to draft a GBV policy and implementation plan.

\section{Critical junctures and ideas}

Although at the time, it was referred to as 'rape', 'sexual torture', or 'forced marriage', gender-based violence (GBV) became a mobilising issue immediately after the genocide, due to enormously high rates of rape, sexual violence, sexual enslavement and sexual torture during the 1994 genocide against the Tutsis. As related in the previous section, initial mobilisation around GBV came from women's CSOs in Rwanda. Although CSO activism around the genocide law brought sexual violence to the national consciousness in Rwanda, the terms 'gender-based violence' and 'GBV', began circulating in 2003 or 2004 . It was during this period that the idea of drafting a GBV law began to be mentioned by CSOs and the FWP. ${ }^{48}$ One interviewee noted that GBV's profile was raised in 2001, when the law on children's rights was drafted, debated and passed:

'I remember in 2001, when the law to protect children was established, civil society advocated, increased their voices to fight violence. There were the bad practices like guterura [forced marriage supported by parents and communities], gusambanya abana ku ngufu [sexually abusing children]. Many cases for the unwanted pregnancies for young girls, a big number of children had experienced violence in the community and at home. ${ }^{49}$

According to Powley and Pearson (2007: 18), the FWP sought to include men in drafting the GBV bill from the outset. When advocating publicly for the GBV bill, women MPs and CSO representatives appealed to men as fathers and sons, by encouraging them to think about their daughters' or their mothers' safety and security (Powley and Pearson, 2007: 19). They had used similar tactics with great success when advocating for changes to the inheritance laws before women occupied the majority of seats in parliament (Burnet, 2008). As Powley and Pearson (2007: 19) explain, 'men were invited into the discussion as champions of victims' rights, not as the target of the legislation'.

The anti-GBV law and advocacy efforts surrounding it were strongly influenced by international discourses, even if the movement was decidedly Rwanda. For example,

\footnotetext{
${ }^{48}$ Interview with national GBV advisor, international NGO, Kigali, Rwanda, December 2014; interview with programme director, Rwanda Women Network, December 2014.

${ }^{49}$ Interview with senior officer, National Police, February 2015.
} 
several interviewees underlined the influence of both the Convention on the Elimination of All Forms of Discrimination Against Women (CEDAW) and the Beijing Platform for Action on the women CSO members and women MPs who pursued the anti-GBV law and drafted the initial bill. According to a women's civil society leader and a director in the Ministry of Education (MINEDUC), the GBV bill was also influenced by the 2000 UN Security Council Resolution 1325, the 2011 International Conference of the Great Lakes Region on Sexual and Gender-based Violence (ICGLR SGBV) and its Kampala Declaration on Sexual and Gender-based Violence (adopted by Rwanda), ${ }^{50}$ and the 2003 Protocol to the African Charter on Human and Peoples' Rights on the Rights of Women in Africa (Maputo Protocol; ratified by Rwanda in 2004) ${ }^{51}$ Rwanda adopted the Beijing Platform of Action in 1995 and:

'undertook strategic actions aimed at tackling nine identified crucial areas among the 12 critical areas suggested in the Beijing Platform for Action. Rwanda ratified and adhered to a number of international and regional conventions, charters and declarations, including the CEDAW, the Millennium Development Goals (MDGs), the United Nations Security Council Resolution 1325, the Universal Declaration of Human Rights of 10 December 1948, the New Partnership for Africa's Development (NEPAD), International Conference of the Great Lakes Region on Sexual Gender based Violence (ICGLR SGBV) 2011 declaration (slogan = "zero tolerance"), and COMESA, among others. All of these instruments highlight gender as an important approach for sustainable development' (Republic of Rwanda, 2010: 9).

\section{Implementation}

Unlike many other countries that have adopted domestic violence or GBV laws, such as Bangladesh, Ghana and Uganda, Rwanda has had great success with implementation. Rwanda's achievements to date on GBV include the establishment of 17 Isange 'One Stop' Centres for GBV survivors that provide holistic intervention and support; the elaboration of a national strategic plan related to the United Nations Security Council Resolution 1325; enacting gender-sensitive laws and reviewing existing discriminatory laws; creation of anti-GBV and child protection committees in every jurisdiction from the grassroots level to the national level; the creation of the gender desk in the Rwanda National Police, the Rwanda Defence Force and the National Public Prosecution Authority; and the creation of a free hotline to the Rwanda National Police, the Rwanda Defence Force, and the National Public Prosecution Authority (Republic of Rwanda, 2010: 10-11). While reported rates of GBV have increased since the adoption of the GBV policy in 2011, these increases may be attributed to increased identification and reporting of cases due to an institutional framework primed to record these data accurately, or to the increased empowerment of women to report (Thomson et al., 2015: 3). Rwanda's success on this front can be attributed to three primary factors: (1) an established process for the implementation of laws; (2) accountability systems and professional technocratic

\footnotetext{
${ }^{50}$ Interview with consultant and expert on gender, December 2014.

${ }^{51}$ Interview with representative, Transparence-Rwanda, September 2014.
} 
corps at all levels of the government administration; and (3) political will of the elites and powerbrokers and the on-going support of CSOs. These factors have contributed to the broad and in-depth application of the GBV law, which has transformed the legal and institutional framework for survivors of GBV.

\section{Law implementation framework}

The first reason for Rwanda's success is the government's technique for implementing complex laws that propose to transform the modus operandi. When such a law is adopted, a complementary policy is crafted to lay the groundwork for implementation. One of the first such policies was the 2004 land policy adopted in tandem with the 2005 land law. These policies help ensure close alignment of the de facto and de jure state of affairs. The same strategy has been applied to other laws, including the national decentralisation policy and several subsequent laws related to decentralisation and the GBV law and policy.

In the case of the GBV law and GBV policy, the two were not developed together. Instead, the GBV policy was crafted after the law had been adopted. Initially, a comprehensive GBV policy was drafted in 2008 and 2009. Funded in part by the United Nations Children's Fund (UNICEF), this draft policy covered GBV for adults and minors. ${ }^{52}$ Given the very different needs of adult and minor victims, it was determined that the draft policy was deficient, and a new effort to draft separate policies for adults and minors was undertaken in $2010 .^{53}$

The National Policy Against Gender-based Violence was adopted in July 2011 (MIGEPROF, 2011). The document grounded the ideas and strategies of GBV national policy in the MDGs, the Vision 2020 strategic plan, the Economic Development and Poverty Reduction Strategy (EDPRS), and the national decentralisation policy. Most importantly, the policy recognised that GBV was a multifactorial problem that required a holistic implementation approach (MIGEPROF, 2011: 13). Thus the policy enumerated a set of implementation strategies along with constraints for each objective, and policy actions to be taken to overcome the constraints (MIGEPROF, 2011: 13-16); and then identified all the institutions implicated in these solutions (MIGEPROF, 2011: 17-23). Beyond this innovative, holistic approach, the policy proposed two key innovations that led to successful implementation: (1) creation of 'focal points in district hospitals' (MIGEPROF, 2011: 14), which resulted in the Isange 'One Stop Shop' Centres for GBV victims; and (2) a coordination framework that encompassed national-level institutions all the way down to village-level institutions and local government administrators (MIGEPROF, 2011: 20). The MIGEPROF coordinates activities and holds the budget lines, which it then channels through the Ministry of Health and the National Police for implementation.

\footnotetext{
${ }^{52}$ Personal communication, Burnet, 2010.

${ }^{53}$ Personal communication, Burnet, 2010.
} 


\section{Accountability, professional technocratic corps and coordination}

The second reason for GBV implementation success is the professional technocratic corps at all levels of the government administration, the accountability systems put in place through performance contracts and annual review, and the coordination of state institutions. Several state institutions played key roles in implementation, including MIGEPROF and the Prime Minister's Office, the Gender Monitoring Office, the Ministry of Local Governance, the Ministry of Justice, the National Policy, and the FWP. In terms of implementation, there was strong collaboration among different government entities responsible for implementation. For example,

'The Ministry of Health worked hand in hand with the National Police and the Ministry considered the instructions from the National Police for medical assistance. The Ministry of Justice played a big role in the judiciary aspect, based on the information from Ministry of Health and the National Police. There is a visible chain of command and collaboration among all concerned parties.' $^{54}$

These efforts were coordinated by the Prime Minister's Office and the MIGEPROF:

'All institutions have the instructions from the prime minister regarding which activities are to be done. We know the medical activities, judiciary activities, psychological, police, etc. We know the channel for the collaboration. Police have to investigate, to write the first document and continue the process to present the document and send the victim to the medical services and judiciary services. Police organise the campaign of sensitisation in the rural area and we were helped by the local government, even the civil society.' ${ }^{55}$

At the level of institutions, the Gender Monitoring Office ensured that every government ministry and agency had specific gender goals, tracked results according to those goals, and included budget lines allocated to gender-related goals. The budgetary and programmatic aspects are enforced because the law stipulates that annual budgets cannot be approved by the parliament if the gender-related goals are absent or not funded. Another reason for successful implementation of the GBV Law is the large national budget to prevent and fight GBV. ${ }^{56}$

A key institutional innovation was the creation of the Isange One Stop Centres for GBV victims. The first Isange Centre was created in 2009 in the Kacyiru Police Hospital. By 2013, the national police 'had established nine other one stop centres' (Hodari, 2014: 40). ${ }^{57}$ As of November 2015, 17 Isange centres existed around the

\footnotetext{
${ }^{54}$ Interview with GBV officer, Ministry of Health, February 2015.

${ }^{55}$ Interview with senior officer, National Police, February 2015; similar things said in interview with programme director, Rwanda Women Network, December 2014.

${ }^{56}$ Interview with GBV officer, Ministry of Health, February 2015.

57 Jimmy Hodari, 'The Isange One Stop Centre: A holistic approach to sexual and genderbased violence', The Police Chief website,
} 
country with the goal of having 30 , one in each district by the end of $2017 .^{58}$ In 2014 , the 'Isange One Stop Center Scale Up Project was launched with an aim of establishing this multidisciplinary service in all 44 district hospitals' (Thomson et al., 2015: 9). The Isange Centre emerged from two parallel initiatives. First of all, a coalition between the National Police and UN Women led to the creation of gender desks in district police departments. ${ }^{59}$ The creation and existence of gender desks in important institutions like the National Police, the Rwanda Defence Forces, and health centres have helped with implementation of the GBV law. ${ }^{60}$ Shortly after the GBV law passed, the FWPs lead many workshops on GBV where, civil society, National Police and the Ministries recommended the creation of "focal points" in district hospitals to serve GBV victims. ${ }^{61}$ The 2011 GBV policy included the creation of focal points as one of its key strategies. These parallel efforts eventually resulted in the creation of the Isange One Stop Centres, which provide holistic support (medical, legal, economic and psychological) to GBV victims. International partners also supported these efforts. A World Bank programme running from 2010 until 2017 supports the Isange One Stop Centres in every district nationwide. ${ }^{62}$ Throughout the process, UN Women sponsored the meetings and consultations necessary for implementation of the law. ${ }^{63}$ The UN Agencies like UNWOMEN gave financial and technical support to some offices like the gender desk; helped institutions to train, to elaborate the tools and to provide some studies on GBV issues. ${ }^{64}$

Although the Isange One Stop Centres have been an important innovation, they have not solved all problems. A 2013 evaluation of the first Isange One Stop Centre cited several problems with the model, including: the requirement that victims report crimes to the police to receive services; inconsistent access to legal services; lack of follow- up with victims once they leave the Centre; and the lack of integration with community services outside of the hospitals and police (Bernath and Gahongayire, 2013: 8-10).

The collaboration between the Rwandan National Police and the judiciary was key to addressing issues of impunity related to GBV. ${ }^{65}$ Following adoption of the GBV law, the National Police investigated alleged GBV crimes with greater vigour, kept detailed records to make annual reports, and transmitted awareness-raising messages through the media. ${ }^{66}$ Their capacity was reinforced through international cooperation, trainings and the creation of investigational protocols. Following the

http://www.policechiefmagazine.org/magazine/index.cfm?fuseaction=display arch\&article id= 3450\&issue id=82014 (accessed 31 December 2015).

58 'Rwandan Isange One Stop model to tackle gender based violence', Rwanda News Agency website published on 5 November 2015: http://www.rnanews.com/national/10986-rwandanisange-one-stop-model-to-tackle-gender-based-violence (accessed 31 December 2015).

${ }^{59}$ Interview with consultant and expert on gender, December 2014.

${ }^{60}$ Interview with national GBV advisor, International NGO, Kigali, Rwanda, December 2014.

61 Interview with senior officer, National Police, February 2015.

62 Interview with GBV officer, Ministry of Health, February 2015.

63 Interview with senior officer, National Police, February 2015.

${ }^{64}$ Interview with consultant and expert on gender, December 2014.

65 Interview with representative, Transparence-Rwanda, September 2014.

${ }^{66}$ Interview with national GBV advisor, international NGO, Kigali, Rwanda, December 2014. 
investigation phase, the judiciary then took over cases. The judiciary's capacities were reinforced through staff allocated for GBV cases and the creation of the Maisons d'accès à la justice (MAJ) in each district. The MAJ have three staff in each district who are responsible for accompanying alleged victims during questioning and when they appear in court. ${ }^{67}$ The MAJ report the information to the Gender Monitoring Office so that it can assess how GBV cases are resolved.

Another key innovation in terms of implementation is the inclusion of gender and GBV in the performance contracts (imihigo) of local officials. ${ }^{68}$ As described by Booth and Golooba-Mutebi (2012: 392, 392fn52),

'administrators are motivated and disciplined by an unusually effective form of performance-based contracting linked to the neo-traditional practice called imihigo ... that gets its force from the unusual level of backing, monitoring and enforcement applied to it from the President's office downwards.'

Because gender mainstreaming was a foundational pillar of the Vision 2020 strategic plan and the EDPRS, gender indicators have been included in the annual performance contracts of local officials. This technocratic solution meant that local officials did not have a choice about whether or not to pay attention to gender issues or to implement the GBV law and policy.

\section{Political will of elites and support of civil society organisations}

The third reason for implementation success was the political will of the elites and powerbrokers within the RPF and the on-going support of CSOs. The 2010 National Gender Policy cited 'the existence of genuine political commitment at the highest level of decision making provides great opportunities for success' as one of the key opportunities for implementing the national gender policy (Republic of Rwanda, 2010: 16). 'The women MPs never cease to talk about the bill and communicate these rights to women everywhere in Rwanda'. ${ }^{69}$ In terms of implementation and realising the rights guaranteed by the GBV law, the national police and CSOs have been vital. $^{70}$ The international NGO, ActionAID, worked with the local CSO, Haguruka, to raise awareness among women about their rights and about GBV. ActionAID gave technical and financial support to CSOs. ${ }^{71}$ Among CSOs, the creation of Rwanda Men's Resource Centre (RWAMREC) and its nationwide awareness raising programmes has had a significant impact in changing the attitudes and beliefs of ordinary male citizens vis-à-vis GBV.

Civil society has played a key role in implementation of the GBV law by raising awareness in communities; providing economic support to victims; advocating for the

\footnotetext{
${ }^{67}$ Interview with national GBV advisor, international NGO, Kigali, Rwanda, December 2014.

${ }^{68}$ Interview with national GBV advisor, international NGO, Kigali, Rwanda, December 2014.

${ }^{69}$ Interview with representative, Rwanda Men's Resource Centre, September 2014.

${ }^{70}$ Interview with representative, Rwanda Men's Resource Centre, September 2014; interview with representative, Transparence Rwanda, September 2014.

${ }^{71}$ Interview with national GBV advisor, international NGO, Kigali, Rwanda, December 2014.
} 
law; conducting public policy research and evaluations of the One Stop Centres during the pilot phase; and advocating for implementation of the recommendations coming out of their studies. ${ }^{72}$ Civil society has been key in terms of raising awareness and disseminating information about the GBV policy, especially Pro-Femmes Twese Hamwe, RWAMREC, Haguruka, Transparence Rwanda. ${ }^{73}$ The national grassroots consultative process, which was organised by MIGEPROF and implemented through the women's councils at every level of government, was fundamental to building acceptance for the GBV law in communities. ${ }^{74}$.

With implementation of the GBV Act, things have changed in many ways on the ground. 'GBV is punished and people known that it is a success'. ${ }^{75}$ 'People know their rights. In the past, no parent accepted to declare the violence inflicted of their children, they kept it a secret. Now the parents whose children are violated declare the violence inflicted to them'. ${ }^{76}$ The new platform, Umugoroba w'ababeyeyi, or Parents' Council, organised nationwide by local government officials, brings together male and female parents to discuss strategies that can be taken by family members to improve on their relationship, preventing and resolving conflict that can arise in their households, neighbourhood or elsewhere. In this platform at the village level, it has provided opportunities to listen and give advice to parents or children. In these forums, they can discuss GBV, especially domestic violence in all its forms. So, it is managed by the National Women's Council and local authorities are involved to mobilise citizens. ${ }^{77}$ Despite this progress, some victims of domestic violence remain reluctant to report their abuse. Because the Isange One Stop Centres require victims to report their abuse to the police to receive services (Bernath and Gahongayire, 2013), they often remain silent. In their study of intimate partner violence in Rwanda, Mannell and Jackson (2014: 6-9) identified three main structural factors that made victims reluctant to report their abuse: (1) poverty and economic dependence; (2) the culture of silence around domestic violence; and (3) social and cultural norms deeming many types of domestic violence to be normal.

Although there was widespread support for the bill, there were some dissenting voices on certain provisions within the law. Interviewees, however, were reluctant to speak on the record about these dissenting voices. In particular, the provision defining marital rape as a crime met with some criticism because of cultural understandings about sexual intercourse, marriage and consent.

\section{Policy implications}

The adoption and implementation of the anti-GBV law reflects the importance of two key factors about the broader dynamics of Rwanda's political settlement and the promotion of gender equity initiatives: the importance of elite support; and the impact

\footnotetext{
${ }^{72}$ Interview with national GBV advisor, international NGO, Kigali, Rwanda, December 2014.

73 Interview with consultant and expert on gender, December 2014.

${ }^{74}$ Interview with current MP, former CSO leader, Kigali, September 2014.

${ }^{75}$ Interview with senior officer, National Police, February 2015.

${ }^{76}$ Interview with senior officer, National Police, February 2015.

77 Interview with GBV officer, Ministry of Health, February 2015.
} 
of technocrats in the government administration. Even though the GBV law was the first (and perhaps only) legislation that had originated in parliament since the 1994 genocide, it received strong support from the President's Office, the Prime Minister's Office, and the MIGEPROF. The MIGEPROF coordinated the discussions with gender institutions (women's councils, women's CSOs, women's caucus, etc.). The CSOs and media took the lead in public advocacy and generating consensus. The president and prime minister approved the law once passed by parliament. The national grassroots consultative process, along with intensive revision of the draft bill, slowed down adoption of the measure, but it met with little opposition along the way. The few dissenting voices did not speak publicly about their opposition because they perceived it as the political will of the ruling coalition. Given the strong support for the GBV law among elites, elections and clientelist politics were irrelevant to the passing of the GBV bill or implementation of the policy. After adoption, Rwanda's well-oiled technocratic machine in the executive branch and gender mainstreaming apparatus ensured vigorous implementation of the law.

\section{Policy case 2: Gender parity in education}

The international community and the Rwandan government celebrate the country's success in achieving gender parity at the primary and secondary levels in the 2000s and attaining the MDGs in education well before their target dates. Rwanda is one of the top three performing countries globally with regard to achieving universal primary education (UPE) goals (UNESCO, 2014). The story of gender parity in education in Rwanda is quite different from that of the GBV law, because the government and, more importantly, political elites, had theoretically supported girls' parity in education for decades before the goal was achieved. Given this long-term formal commitment to gender parity in education, but slow progress towards UPE, it can be difficult to disentangle the gender story to understand precisely what led to the sudden realisation of these commitments after decades of rhetoric and what interventions helped to achieve this success. Analysing why these achievements were not attained until the 2000s may help policymakers address challenges related to the quality of education and gender achievement gaps. According to Htun and Weldon's (2010) typology of gender-specific policy reforms, reforms to achieve gender equality in education can be understood as an ameliorative policy in their typology, since it alleviates gender-based class inequities.

The gender achievement gap in education dates back to the colonial era in Rwanda. Early in the colonial project, Christian missions built many small schools in rural areas that taught one or two years of a basic curriculum in reading, morals, religion and hygiene; in short, they offered an education sufficient for religious conversion (Hoben, 1989: 11). The missionaries also built a small number of high-quality schools intended to educate an indigenous African clergy (ibid.). The Belgian colonial state created formal schools in the mid-1920s to educate a tiny portion of the population (the boy children of nobles and children of mixed African and European heritage) who were destined to become clerks, local government officials or technical aids (Hoben, 1989: 12). Girls were formally excluded from the elite schools. They, along 
with other boy children, were encouraged to attend rudimentary rural schools so that they could convert to Christianity, participate in worship and read the Bible. Late in the colonial era, a school was founded to train female nurse-midwives who could attend women giving birth in health centres around the country. ${ }^{78}$ At independence, a new law opened primary schools 'to all regardless of gender, ethnicity, and geographic origin' (King, 2013: 85). Despite the change in law, many barriers to education remained for girl children from the 1960s through the 1980s.

Figure 1. Primary enrolment (in millions) for Sub-Saharan Africa (1985-2012) ${ }^{79}$

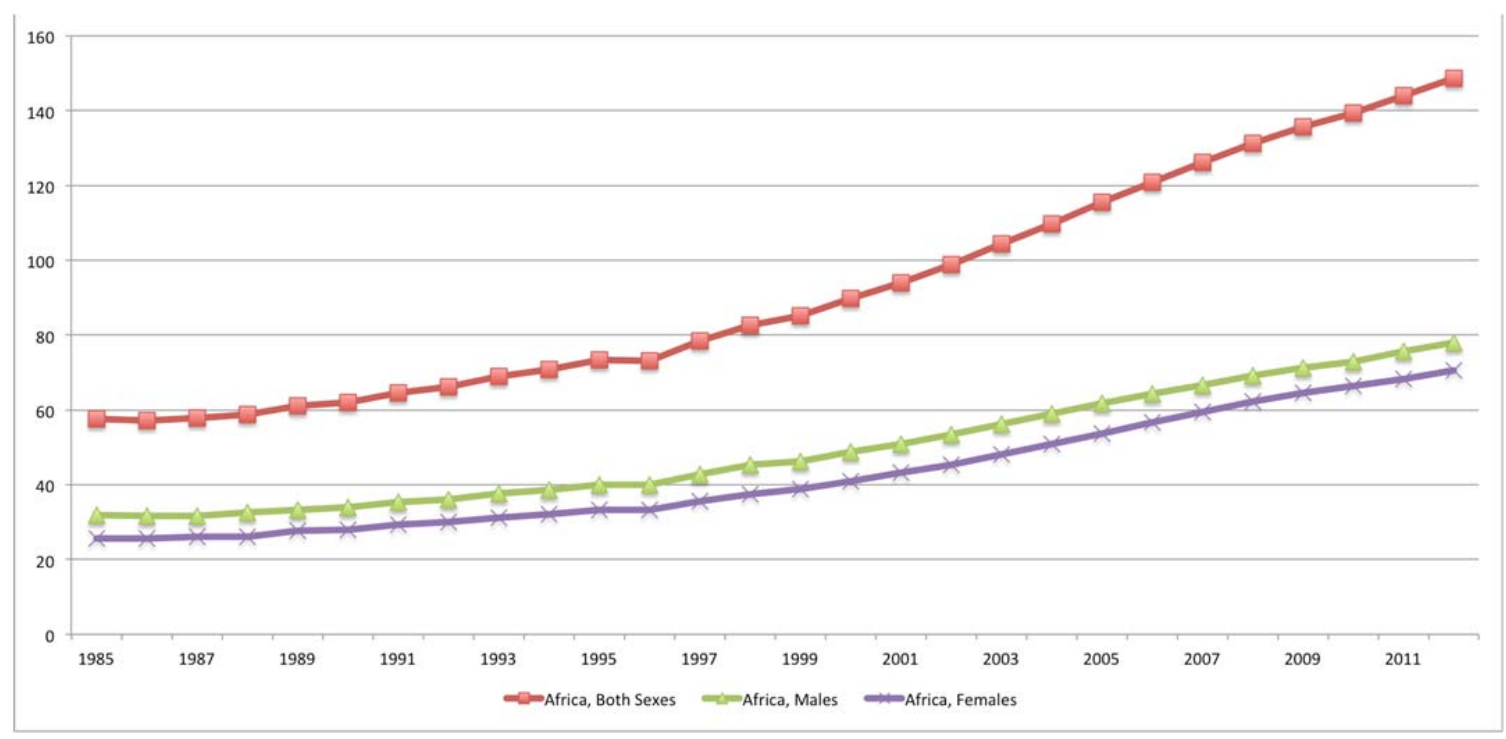

As early as 1986, the Rwandan government stated that gender parity in education was a national priority. The Ministry of Planning's five-year plan explicitly stated, 'increased access to schooling and improved status had to be accorded to women as part of the strategy for limiting population growth' (MINIPLAN, 1986, cited in Hoben, 1989: 102). In the early 1980s, 'girls' enrolments nearly equalled those of the boys' in primary schools, but girls were much less likely to pass the completion exams and qualify for admission to secondary school (Hoben, 1989: 101) (see Figure 2). Furthermore, many Rwandan children, both boys and girls, were not enrolled in school at all; and even more did not attend regularly once enrolled. Only one-third of secondary school students in the 1980s were girls, and less than 17 percent at university level (Hoben, 1989: 101-102). Despite the inclusion of gender equity in education in the strategic plan, virtually no gains were made, because the Ministry of Primary and Secondary Education did not pursue gender quotas and did not increase the number of classrooms or teachers to accommodate more students (ibid.). Perhaps, more importantly, the vast majority of obstacles to girls' education were social and economic. Poor children and girls had unequal access to primary education 'because people had a mentality that it was boys who have to study and

\footnotetext{
${ }^{78}$ Interview by Burnet, West province, Rwanda, 2001.

${ }^{79}$ World Bank data.
} 
that it was girls who had to stay home to help the family' (King, 2013: 86). The reintroduction of school fees by 1988 meant that 'the cost of primary school soon amounted to more than US\$18 per child per year, at a time when GDP per capita was only US\$255' (King, 2013: 86).

The liberation war (1990-94) and the 1994 genocide against the Tutsis had significant impacts on education in Rwanda. During the war, internal displacement of the population interrupted many children's education. Then the 1994 genocide destroyed the national educational infrastructure, especially in terms of qualified educators and policymakers. School buildings were frequently damaged or destroyed. The government of Rwanda did not report education data to the World Bank for several years (1993-96 and 1998). After the critical juncture of the 1994 genocide against the Tutsis, Rwanda made very rapid gains in terms of gender parity in education at the primary and secondary levels in the 2000s. With the influence of the MDGs, Rwanda made a concerted effort to increase enrolments. When compared with the rest of Sub-Saharan African (see Figures 1 and 2), Rwanda's stellar achievements in terms of increasing enrolment and achieving gender parity in primary education are clear.

Figure 2. Primary enrolment (in thousands) for Rwanda (1985-2013) ${ }^{80}$



\section{Actors, institutions, incentives and interests}

The key actors in the expansion of girls' access to primary education are the political elite and the civil bureaucracy. The government of Rwanda's stated commitment to universal education for all is quite old, but the country made only incremental progress in the 1980s (see Figure 2). Rwandan women elites (i.e. those women who

\footnotetext{
${ }^{80}$ World Bank data.
} 
had achieved a high level of educational attainment and salaried work in the government or civil society sector) in the 1980 s and early 1990 s remained well aware of the need for awareness-raising campaigns and advocacy on behalf of girls' education. CSOs documented the numerous impediments to girls' education and advocated for the government to take action against them. When Agathe Uwilingiyimana became the minister of education in 1992, and then the first female prime minister in 1993, she used her position to push gender parity in education as a national priority. ${ }^{81}$ It was not until after the 1994 genocide against the Tutsis (discussed below) that Rwanda made rapid progress in gender parity in education.

Given the government's officially stated commitment to universal education dating back to the 1980s, it can be difficult to pinpoint the key actors who relaunched this initiative in the late 1990s and ensured that it became a pillar of the Vision 2020 strategic plan in 2000. There is no doubt that technocrats working in the MINEDUC and the ministry, as an institution, played key roles in prioritising gender equity in education and implementing this aspect of the Vision 2020 strategic plan once it was adopted. For example, the 2003 education sector policy stated:

\begin{abstract}
'Education is a fundamental human right and an essential tool to ensure that all Rwandese citizens - women and men, girls and boys - realize their full potential. ... The major aims of education and training should be: 1) to give all Rwandese people - women and men, girls and boys - the necessary skills and values to be good citizens' (MINEDUC, 2003: 4).
\end{abstract}

We were unable to document the involvement of the MIGEPROF in this early stage of prioritising gender equity in education, but nearly all interviewees cited MIGEPROF and the Prime Minister's Office as key actors in promoting girls' education.

In civil society, Pro-Femmes Twese Hamwe played an important role as the coordinating body, but the Rwanda chapter of the Forum for African Women Educators (FAWE-Rwanda) was at the vanguard of girls' education. FAWE-Rwanda was officially chartered in 1997, but its roots went back to before the genocide, when Agathe Uwilingiyimana was a founding member of the international organisation. From 1997 onward, FAWE-Rwanda led the charge for gender equity in education through awareness-raising, advocacy, scholarship programmes, mentoring, programmes to address child labour, and founding the FAWE-Rwanda Girls' School to cultivate excellence and persistence to completion among female secondary students. FAWE-Rwanda benefited from a close partnership with the Ministry of Education and international funding for its programmes via bilateral aid programmes, philanthropic corporate partnerships, and grant programmes.

Since 2001, the first lady of Rwanda, Jeannette Kagame, made girls' education one of her primary areas of focus in her advocacy activities. In 2001, the Office of the

\footnotetext{
${ }^{81}$ Interview by Kanakuze, Kigali, Rwanda, September 2014; interview with former member, National Education Board, September 2014.
} 
First Lady launched a programme, Protection and Care of Families against HIVIAIDS (PACFA), to improve the quality of life for those living with human immunodeficiency virus infection and acquired immune deficiency syndrome (HIVIAIDS) and to assist their families, especially minor children. As the programme evolved, it took an ever greater focus on education as a means to combat the spread of HIV and to raise the living standards for those already infected. Thus, in 2007, the Imbuto Foundation was founded to carry on this work. Among its many other development-related activities, Imbuto has led a campaign to promote girls' education and helped remove barriers to secondary education among marginalised children (girls and the poor) by offering scholarships for high-achieving students living in poverty to attend secondary school.

Since the 2003 education policy decentralised primary education to district-level governments, local governments and local officials have played a key role in increasing enrolment and completion rates for all children, especially girls. Local officials were keenly motivated to meet these goals, since they were held accountable through their performance contracts and annual reviews. Once primary education fees were eliminated as part of the sectoral reform included in the 2003 education policy, a key impediment to enrolment was the lack of schools in close proximity to residents in rural areas and insufficient classrooms to accommodate all students. In response to this need, local government officials mobilised communities to contribute labour to build new schools and new classrooms, using materials provided by the MINEDUC via funding from bilateral aid. Local residents had a strong motivation to participate in these projects, because they promised better access to education for their children.

The international community played an important role in the expansion of primary education, including education for girls. According to one interviewee, a coalition of key actors, such as local government authorities, parents, MINEDUC, parliament, as well as international organisations like UNESCO and UNICEF, collaborated to push forward the issue of gender equity in education. ${ }^{82}$ International institutions that influenced the ideas around gender parity included USAID, the MDGs, FAWE, the CEDAW, the UN, UNICEF, and the Beijing Conference Declaration. ${ }^{83}$

The international community, comprising the UN bodies, bilateral aid agencies, partner governments, and international development NGOs, shaped Rwanda's education trajectory in two key ways. First of all, the creation of the MDGs and the inclusion of universal education for all spurred on the government of Rwanda to fasttrack this goal, which was within reach. For example, in an analysis of the Rwandan education sector by the Overseas Development Institute in 2009, the MDGs for UPE are listed as attainable, and gender equality in primary and secondary education as already achieved (ODI, 2009: 4). Second, the international community provided funds to help cover the costs of construction materials, of training teachers, and of

\footnotetext{
${ }^{82}$ Interview with statistician, Ministry of Education, January 2015.

${ }^{83}$ Interview with representative, Forum of African Women Educators in Rwanda, November 2014; interview with consultant and expert on GBV, October 2014; interview with consultant and expert on gender, November 2014.
} 
developing new curricula in response to education reforms. In 2006, Rwanda joined the Global Partnership for Education (GPE), which increased international assistance to the education sector. Since then, Rwanda has received a total of $\$ 175$ million in disbursements from GPE to support the education sector. ${ }^{84}$ International organisations, such as UNICEF and UN Women, have worked with the government and civil society to address girls' access to education, by offering technical support and funding the construction of new schools. ${ }^{85}$

\section{Critical junctures and ideas}

Several critical junctures marked key moments in the progress towards gender equity in education: (1) the 1994 genocide against the Tutsis; (2) adoption of the Vision 2020 strategic plan in 2000; (3) the decentralisation of education in the 2003 education sector reform policy; and (4) Millennium Challenge Corporation (MCC) Threshold grant to Rwanda.

The first critical juncture in terms of gender parity in education was the 1994 genocide against the Tutsis, which had a devastating effect on education in Rwanda. The physical infrastructure for education was destroyed, and the human capital was decimated. The Rwandan government did not report educational statistics to UNESCO or the World Bank between 1993 and 1996. It began reporting them regularly again in 1999. During this time period, the majority of Rwandan children did not attend school, with the exception of those who spent time in refugee camps, which offered rudimentary primary education. Inside the country, schools restarted as quickly as possible, but it took several years for the national government to rebuild the MINEDUC's infrastructure so that it could organise primary completion exams, secondary promotion exams, and secondary completion exams. When the government again began reporting education information, primary completion rates were abysmally low (see Figure 3). The destruction of the country's education system, in terms of physical, human and curricular infrastructure, allowed for the government to revamp the system. Major educational reforms in 1998, which formalised mandatory instruction in all three languages (Kinyarwanda, French and English); in 2003, which decentralised administration of primary school education; and in 2008, which eliminated French from the core curriculum, contributed to the reinvention of the national curriculum.

\footnotetext{
${ }^{84}$ Global Partnership for Education website, http://www.globalpartnership.org/country/rwanda (accessed 14 December 2015).

${ }^{85}$ interview with parent and citizen, February 2015.
} 
Figure 3. Primary completion rates: Sub-Saharan Africa and Rwanda $(\mathbf{1 9 8 5 - 2 0 1 3})^{86}$

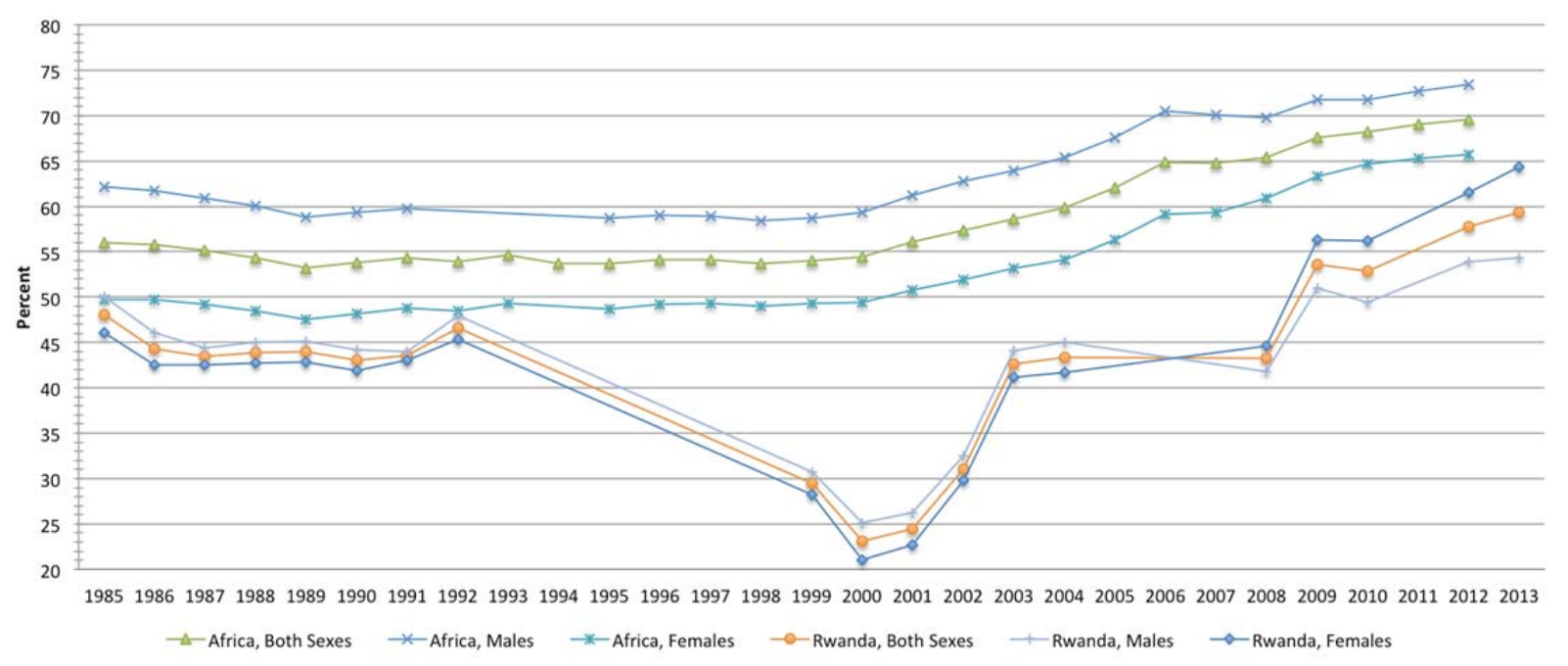

As discussed earlier, a key reason that gender equality took off after the 1994 genocide was the changed ideology of the dominant party. Before the genocide, the government said that it was committed to women's rights, but it 'allowed patriarchal ideas to dominate'. ${ }^{87}$ The RPF took a different approach. As a result, sexist ideas are 'no longer acceptable to say out loud in public', even if they have not disappeared completely. ${ }^{88}$

The second critical juncture, which appears to have changed Rwanda's trajectory, is the adoption of the Rwanda Vision 2020 strategic plan in July 2000. This ambitious strategic plan sought to set Rwanda on course to become a middle-income country by the year 2020 , with an economy based primarily on agricultural exports, the service and hospitality sector, and information communication technology (ICT). As in the strategic plan of a corporation, all government planning, policies and activities since its adoption have been tied to the plan's key objectives. Vision 2020 included the MDG of universal education for all (Republic of Rwanda 2000: 15) and set the goal of 100 percent net primary school enrollment by 2010 (Republic of Rwanda 2000: 27) (see Table 4). The MDGs and Vision 2020 helped to get the Rwandan government and the international community to recommit to the long-held goal of universal education for all and achieving gender parity in education. In the same year, the MINEDUC created the 'Education for All' programme and campaign. ${ }^{89}$ The awareness-raising campaign attempted to address the cultural reasons for girls' exclusion from primary education.

\footnotetext{
${ }^{86}$ World Bank data.

${ }^{87}$ Interview with women's civil society activist, December 2014.

${ }^{88}$ Interview with women's civil society activist, December 2014.

${ }^{89}$ Interview with statistician, Ministry of Education, January 2015.
} 
Table 4. Rwanda Vision 2020 education targets

\begin{tabular}{|c|c|c|c|c|c|}
\hline Indicator & $\begin{array}{l}2000 \\
\text { Actual }\end{array}$ & $\begin{array}{l}2010 \\
\text { Target }\end{array}$ & $\begin{array}{c}2012 \\
\text { Actual }\end{array}$ & $\begin{array}{c}2020 \\
\text { Original } \\
\text { target }\end{array}$ & $\begin{array}{c}2020 \\
\text { Revised } \\
\text { target }\end{array}$ \\
\hline Literacy level & 48 & 80 & 83.7 & 100 & 100 \\
\hline $\begin{array}{l}\text { Net primary school enrolment } \\
\text { (\%) }\end{array}$ & 72 & 100 & 100 & 100 & Met \\
\hline $\begin{array}{l}\text { Gross primary school enrolment } \\
\text { (\%) }\end{array}$ & NA & 100 & 127 & 100 & Met \\
\hline $\begin{array}{l}\text { Secondary school transitional } \\
\text { rate (\%) }\end{array}$ & 42 & 60 & & 80 & \\
\hline $\begin{array}{l}\text { Gross secondary school } \\
\text { enrolment (\%) }\end{array}$ & 7 & 40 & 35.5 & 60 & 98 \\
\hline $\begin{array}{l}\text { Rate of qualification of teachers } \\
\text { (\%) }\end{array}$ & 20 & 100 & & 100 & \\
\hline $\begin{array}{l}\text { Professional and technical } \\
\text { training centres }\end{array}$ & NA & 50 & & 106 & \\
\hline $\begin{array}{l}\text { Rate of admission in tertiary } \\
\text { education. }\end{array}$ & 1 & 4 & 38 & 6 & 65 \\
\hline $\begin{array}{l}\text { Gender equality in tertiary } \\
\text { education ( } F \text { \%) }\end{array}$ & 30 & 40 & & 50 & \\
\hline
\end{tabular}

The third critical juncture was the decentralisation of education policy implementation adopted with the 2003 education sector policy. This policy decentralised the implementation of education strategies to the district governments (MINEDUC, 2003: 7-8). As a result, mayors and sector-level executive secretaries became accountable for achieving the universal-education-for-all milestone. This policy localised accountability for primary education, thus increasing its impact. Local government administrators in Rwanda have performance contracts and undergo annual evaluations. With decentralisation, various education-related performance indicators were added to local government officials' performance contracts. In addition, this policy mandated fee-free education in state-run primary schools, to eliminate one of the main barriers to education for the poor and for girls. As a result, there was a rapid increase in primary school enrolment and attendance rates between 2000 and 2005 (see Figure 4).

The fourth critical juncture was the MCC Threshold grant to Rwanda, which began in 2008 and ended in 2011. Although the threshold grant focused on issues related to political freedom, civil society and human rights, it put Rwanda on track to qualify for a lucrative MCC Challenge grant, where universal education for all would be a metric of success. Thus, the MCC Threshold grant helped to keep universal education for all as a top priority, because the central administration saw that this MDG was within reach. The 2010 National Gender Policy stated that the MDGs and the NEPAD were 'key political commitments ... to accelerate the empowerment of women by ensuring 


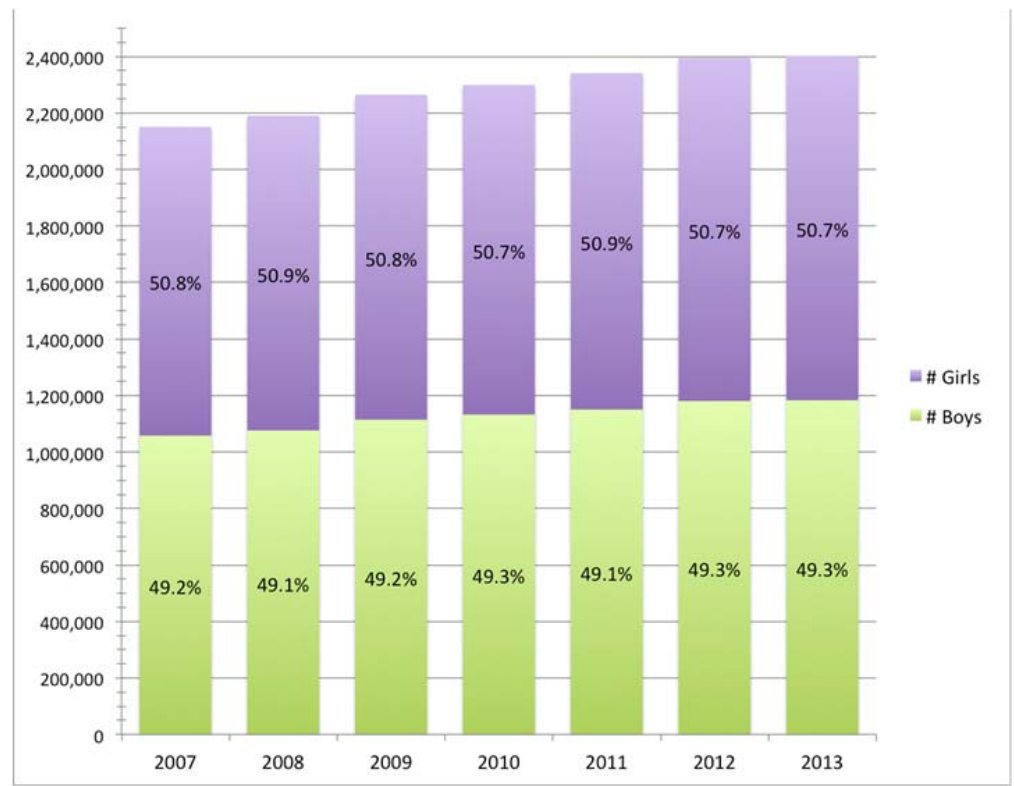

Figure 4. Primary enrolment by gender: Rwanda (2007-13) ${ }^{90}$

that the partnership is linked to the MDGs' (Republic of Rwanda, 2010: 13). Furthermore, it committed the Ministry of Gender, specifically, and the government of Rwanda, more broadly, to undertaking a set of initiatives to increase girls representation, retention and success in secondary and tertiary education in Rwanda (Republic of Rwanda, 2010: 23-24).

In the aftermath of the 1994 genocide against the Tutsis, education became the cornerstone of building a peaceful society in Rwanda. In this context, reducing the gender disparity in education and providing basic education for all were framed as keys to the economic development of the country, to reducing poverty, and to building a peaceful future for the country. As early as 1999, Aloysie Inyumba, MIGEPROF, spoke about gender parity in education as an important issue in the country's development. ${ }^{91}$

Between 1994 and 2010, when Rwanda achieved gender parity in secondary education, Rwandan culture underwent a sea change in terms of dominant ideologies about gender (see Figure 5). Between 1997 and 2011, women experienced 'increased respect from family and community members, enhanced capacity to speak and be heard in public forums, greater autonomy in decision making in the family, and increased access to education' (Burnet, 2011: 303). While it was normative for elite women to work prior to the 1994 genocide, their husbands often controlled their salaries and, by law, the man was the de facto head of household (Jefremovas, 2002; Burnet and RISD, 2003). The 2003 constitution's gender quota wrought an obvious change in the representation of women in government offices from the national level down to the grassroots. The presence of more women in decisionmaking roles 'gave girls the self-confidence to believe that they could achieve these

\footnotetext{
${ }^{90}$ Rwanda Ministry of Education data.

${ }^{91}$ Interview with journalist, December 2014.
} 
things and hold these jobs'. ${ }^{92}$ As more professional opportunities opened up to women, older women returned to school to complete their studies. ${ }^{93}$ Their actions set

Figure 5. Secondary enrolment by gender: Rwanda (2007-13) $)^{94}$

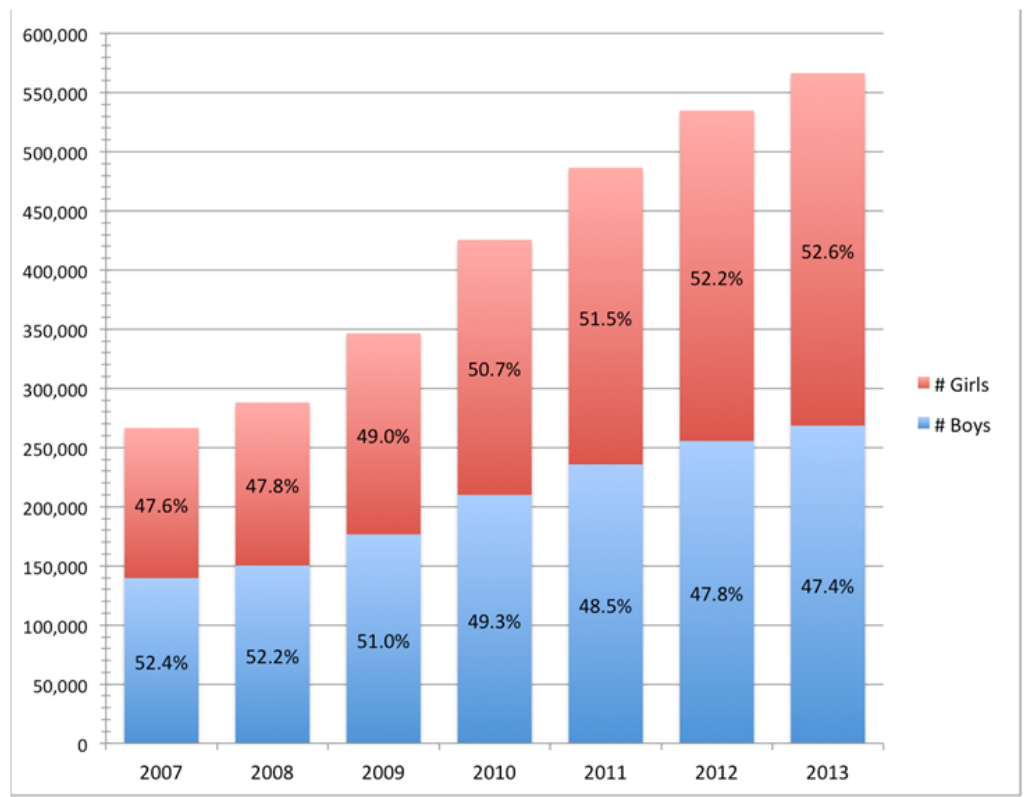

an example and inspired younger women to stay in school (ibid.). Girls 'have new opportunities to pursue education and now grow up being told by NGOs and state officials that education is the key to "the good life"' (Berry, 2015: 14). Public advocacy by the first lady, Jeannette Kagame, the Imbuto Foundation and FAWE-Rwanda helped to mainstream the notion that girl children can and should be educated as well as boy children. While women's CSOs in Rwanda had pointed to gender parity in education as a key to the nation's development since long before the 1994 genocide, this high profile awareness-raising by the first lady and her foundation helped to tip the balance and give increased visibility to the issue. This high profile awarenessraising about girls' education and increased career opportunities for educated women have had a significant impact on girls and their families.

Another example of the ways that ideas impacted change in the education sector is the mainstreaming of gender equality in the national curriculum. The MINEDUC's social studies curriculum goals state:

'Educate a full citizen who is liberated from all kinds of discrimination, including gender based discrimination, exclusion and favouritism ... Eliminate all causes and obstacles, which can lead to disparity in education, be it by gender, disability, and geographical or social group' (cited in Mills and Wiesemes, 2012: 95).

\footnotetext{
${ }^{92}$ Interview with director, Roman Catholic primary school, December 2014.

${ }^{93}$ Interview with parent and citizen, February 2015.

${ }^{94}$ Rwanda Ministry of Education data.
} 
Building an inclusive society became a cornerstone of Rwandan national education policy in the aftermath of the 1994 genocide against the Tutsis.

\section{Resistance to gender equality in education}

Gender equality in education met with greater public resistance than that towards the anti-GBV law and policy. Some men challenged affirmative action in education for girls and women by claiming that it was moving discrimination from girls to boys. ${ }^{95}$ We were not able to isolate the precise reasons for this difference, but perhaps it is due to the material reality that UPE had already been the official policy for decades, even if it had not been implemented effectively. Thus, according to interviewees, people in communities felt more comfortable voicing the deeply embedded cultural resistance to the change in normative ideas than they did resistance to the anti-GBV law and policy. Still, we did find some interviewees who insisted that there was no resistance to gender equity in education: 'There is no resistance, with the exception of some few people with a bad understand based on the culture that still considers men to have more rights and privileges than women'. ${ }^{96}$

Many interviewees reiterated that the key to combatting ideological resistance to gender equity in education in rural communities was the public commitment of political elites. For example, one interviewee said, 'men's resistance to promoting girls' and women's education was high. They were fearful of "women power". Thankfully, President Paul Kagame demonstrated his high commitment to women's education and gender equality'. ${ }^{97}$ Others explained the resistance to educating girls as part of the cultural logics of economic investment in children:

'Some parents resisted investing in girls' education based on the belief that girls' purpose is to get married and produce children and look after the household. Men sometimes said, "Ariga se ngo azatware imisozi?" Meaning "Is she studying to be a chief of a village/hill?" Or, "Diplome y'umukobwa ni umugabo", meaning: "a girl's diploma is a husband". The good thing this attitude is dying fast. ${ }^{98}$

According to this rationale, which still dominated up until the mid-2000s, a young woman with too much education risked not being as desirable a spouse. But as more and more professional opportunities opened up to educated women, education quickly came to be perceived as increasing a daughter's potential for marriage (Burnet, 2011).

Even as normative ideas about gender and education have changed, femocrats and political elites remained attuned to persisting gendered ideas about intelligence and

\footnotetext{
${ }^{95}$ Interview with education expert and consultant, September 2014; interview with parent and citizen, February 2015; interview with women's civil society activist, December 2014.

${ }^{96}$ Interview with advisor, Ministry of Gender and Family Promotion, December 2014.

${ }^{97}$ Interview with director, Roman Catholic Secondary School, September 2014.

${ }^{98}$ Interview with teacher, primary school, November 2014; interview with director, Ministry of Gender and Family Promotion, October 2014.
} 
education. As noted by one interviewee, 'the number of girls who have entered school to study sciences and technology is still low. Some affirmatives actions, those dispositions to promote girls in education, met some resistance from parents'. ${ }^{99}$ As discussed in detail below, the president and first lady countered these ideas publicly and government and civil society programmes sought to overcome them.

\section{Implementation}

The achievement of gender equity in primary and secondary education in Rwanda can be attributed almost entirely to implementation. While it is true that international policy frameworks influenced the adoption of domestic policy frameworks, the majority of countries in Sub-Saharan Africa, including many who received MCC Challenge grants, adopted the very same international policy frameworks and yet they made disappointing progress on the Universal Education for All MDG. In addition, the Rwandan government had long espoused gender parity in education as a goal (as described in detail above), but it had not committed the resources necessary to address the barriers to education for girls, specifically, or the poor and marginalised, in general, until the change in government following the genocide and the adoption of a new implementation framework. Key to implementation of this policy initiative in the Rwanda case was: (1) the alignment of international and national development priorities; (2) decentralisation of primary education to local government; and (3) political will of elites and support from CSOs.

\section{Alignment of international and national development priorities for education}

The alignment of international and national development priorities for education was a key to success in achieving gender equality in primary and secondary education. As detailed above, the international community provided an ideological framework, as well as funding that allowed Rwanda to make rapid movement towards achieving this goal. In 2000, the Vision 2020 Strategic Plan placed UPE and basic education for all among the national development priorities to be achieved by 2015 (MINEDUC, 2003: 6). In 2001, an education reform reduced the enrolment age for primary school. In 2001, a pupil had to be eight years old to enrol in primary school, but as of 2002, the enrolment age dropped to six years. This policy change reduced drop-out rates and unwanted pregnancies, because students were younger as they progressed through their education. ${ }^{100}$ The 2003 education sector policy positioned Rwanda's education policy within the framework of several national key documents, including the Vision 2020 Strategic Plan and the Poverty Reduction Strategic Plan (EDPRS I). The Vision 2020 Strategic Plan stated that the government's primary objective for education was to provide universal primary education by 2010 and subsequently basic education for all by 2015 (MINEDUC, 2003: 6).

The creation of the EDPRS I in 2008 brought another important opportunity for making UPE central to the country's development priorities. The EDPRS included achieving the MDGs of UPE by 2015 and reducing gender inequality in education;

\footnotetext{
${ }^{99}$ Interview with statistician, Ministry of Education, January 2015.

${ }^{100}$ Interview with director, private primary and secondary school in Kigali, December 2014.
} 
the provision of textbooks and relevant curricula at all levels of the system; the training of more teachers, particularly at primary level; and the provision of HIVIAIDS education to all children from an early age.

Rwanda experienced a jump in primary completion rates between 2008 and 2009 (see Figure 3 above). Some interviewees attributed this increase to a set of education reforms, including nine years of Basic Education for All, elimination of tuition and school fees for local schools, construction of additional classrooms in local schools, construction of sanitary rooms and separate toilets for girls, inclusion of education performance indicators in the performance contracts of local government officials, and awareness raising in communities about the importance of children remaining in school and completing their education. ${ }^{101}$

While this set of educational reforms can account for the steady climb in Rwanda's primary school enrolment rates (see Figures 2 and 4), it cannot account for the sudden increase in completion rates between 2008 and 2009 (see Figure 3). The only change that we could identify that can account for this increase was the policy of Nine Years Basic Education for All. The transition rate from primary to secondary school, which rose from 54.60 percent in 2007 to 87.90 percent in 2008, was because of the introduction of the Basic Education for All reform. ${ }^{102}$ Under this policy, children who completed sixth grade primary but who did not score high enough on national exams to win a place in state-subsidised secondary schools continued on in local schools. These students were counted in the national numbers as having completed primary school and transitioned to secondary school.

Women's CSOs also influenced education-related policies through their research on educational barriers and advocacy. For example, women's CSOs helped to identify institutional barriers to girls' and poor children's continued attendance at school as early as the 1980s. One barrier identified was the domestic labour market. Domestic workers were frequently minors whose families were unwilling or unable to continue to pay for their education. These domestic workers worked long hours, cooking, cleaning and taking care of young children, primarily in exchange for room and board and a modest amount of cash (\$20-50 per month). Although such practices are forbidden under Rwandan law, the laws were widely ignored. To help remove this barrier, government employees were told that they must not hire under-aged domestic workers, ${ }^{103}$ and that if they were caught doing so, their own jobs could be endangered. In 2012, the Kigali City Security Council issued guidelines on child labour (United States Department of Labor's Bureau of International Labor Affairs (ILAB), 2013). The guidelines prohibited the employment of children in Kigali City in many different roles, including as domestic servants, street beggars, or porters (ibid.). The guidelines also laid out an awareness-raising programme to be undertaken by local authorities, and calls for a census at the cell administrative level

\footnotetext{
101 Interview with director, Ministry of Education, December 2014.

102 Interview with representative, Forum of African Women Educators in Rwanda, November 2014.

${ }^{103}$ Personal communication to Burnet, Kigali, 2011.
} 
to estimate the prevalence of child domestic workers (ibid.). These measures had the net effect of dramatically reducing the number of minor children employed and made it possible for them to return to school. As discussed in more detail below, other areas identified by women's CSOs, such as menstruation- or pregnancy-related barriers to education, have not yet been tackled on a nationwide basis, although some localised efforts have occurred.

\section{Decentralisation of primary education to local government and accountability}

A national decentralisation effort was launched in 2000 with adoption of the decentralisation policy (ODI, 2009: 5). This set out to decentralise fiscal and administrative oversight of key government functions to the district and sector level, in line with policy initiatives emanating from the World Bank and IMF. There are three primary levels of administration in Rwanda: the national government, the provinces $(n=5)$, and the districts $(n=30)$. Large-scale fiscal decentralisation moved large portions of the national budget to district control gradually, beginning in 2006 (ODI, 2009: 5). According to an ODI study of sector budget support in education, only 2 percent of the total education budget was spent at decentralised levels in 2004, but this figure rose to 44 percent in 2005 (ODI, 2009: 9). In the 2008 budget, 54 percent of the total education expenditures were to be spent at decentralised levels (ibid.). 'It is important to note that none of these transfers are actually transferred to the Districts' accounts. Teachers' salaries are paid directly to teachers' accounts, and capitation grant and school feeding are paid directly to schools' accounts' (ODI, 2009: 10). The district governments create the payrolls for teachers, transmit information on student and teacher numbers per school to the MINEDUC, and process the quarterly requests for the monthly payment transfers to schools (ibid.). In essence, this structure has decentralised responsibility for education to the school level, under the management of school directors and parent boards, with district government oversight. This structure has increased efficiency and flexibility at the school level, so that school directors can make spending decisions focused on activities that will improve educational quality adapted to the situation of the local school (ODI, 2009: 13).

The performance contract accountability system, combined with fiscal decentralisation of education funds, has been key to achieving gender equality in education and UPE for all. Another key innovation in terms of implementation is the inclusion of local education benchmarks in the performance contracts (imihigo) of local officials. As a result, local officials did not have a choice about whether or not to pay attention to primary education or gender parity in education. Performance contracts in the districts include goals related to education. ${ }^{104}$ As with GBV, all mayors have performance indicators tied to education that are in line with Vision 2020, the education sector strategic plan, and all other policies guiding the country's education system. According to the 2000 decentralisation policy, all districts must have a district education plan. Districts directly monitor secondary schools, while sectors monitor primary schools and report the data to the districts (ODI, 2009: 12).

${ }^{104}$ Interview with teacher, primary school, November 2014. 
In addition, districts 'sign "performance contracts" (imihigo) with each head master and evaluate performance regularly' (ibid.).

The net result of this system has been a close collaboration between local government authorities and parents to implement the Nine Years' Basic Education for All policy. 'Two-thirds of new classroom construction was accomplished by parents and one-third by the government'. ${ }^{105}$ The construction of schoolrooms enabled many more children to enrol. ${ }^{106}$ In many communities, primary schools also adopted the practice of 'double-shifting', with half the students studying in the morning and the other half in the evening. In response to pleas for qualified teachers from parents, school directors and local government officials, MINEDUC increased the number of teacher training colleges to five: one in each province, to help meet the need for primary teachers. ${ }^{107}$

All of these strategies to achieve gender equality in education and universal primary education had been outlined in the 2003 education sector policy (MINEDUC, 2003: 10). Thus, although MINEDUC's direct control over the education sector budget has devolved to schools, with oversight from districts, the ministry's strategic planning, leadership and coordinating efforts were instrumental in achieving success. In addition, MINEDUC is key to accountability in terms of education quality, since it handles the national examinations process from beginning to end.

\section{Political will of elites and support of civil society organisations}

The third reason for implementation success was the political will of elites in government and powerbrokers within the RPF and the persistent advocacy by CSOs. As discussed in detail above, the RPF has long been a champion of women's rights and mainstreamed women in the movement since its founding. Beyond this commitment to gender equality, the party also envisioned education as the foundation for building a unified and peaceful society in the aftermath of the genocide.

These priorities have had the support of a cross-section of political elites within the RPF, including First Lady Jeannette Kagame and Aloysie Inyumba (discussed above), and go all the way up to President Kagame. President Kagame has spoken on numerous occasions about education as a key to Rwanda's economic development. The president summed up his personal commitment to gender equality in education in his 2013 speech in Japan: 'Ultimately, the most effective and longlasting guarantee to women's equality and increased participation in economic activity is education - to acquire knowledge and skills'. ${ }^{108}$ The themes of gender

\footnotetext{
105 Interview with journalist, December 2014; also mentioned in interview with advisor, Ministry of Gender and Family Promotion, December 2014.

${ }^{106}$ Interview with teacher, primary school, November 2014.

107 Interview with journalist, December 2014.

108 President Paul Kagame's website, http://paulkagame.com/?p=2415 (accessed 7 November 2017).
} 
equality and education appear regularly in the president's speeches. ${ }^{109}$ Many other prominent RPF leaders have regularly spoken publicly about the importance of education for all Rwandans, including girls.

Rwandan civil society, particularly, women's CSOs, have advocated for gender equality in education for years and conducted public policy research to identify barriers to girls' education. Women's CSOs have long focused on barriers to children's education, by both identifying them through research and seeking ways to remedy them. As discussed above, CSOs identified the domestic labour market as an impediment to girls' education. They also identified poverty and the customary reliance on girl children's work at home. In response to this impediment, incentives were used to encourage girls' attendance and reduce girls' drop-out rates, like regularly giving cooking oil to girls who attend school as a way to motivate parents to send them to school. ${ }^{110}$ At the primary level, CSOs like Haguruka, Réseau des Femmes, and African Evangelistic Enterprise (AEE) played a key role in bringing girls who had dropped out back to school by providing school materials, uniforms and school fees. ${ }^{111}$

Civil society has played a key role in achieving UPE for all by raising awareness in communities and disseminating information about the need to educate girl children. Awareness-raising about the need to educate girls 'played a big role. I cannot forget the [radio] drama called "Son Préférence", which explained the choice for [a] son to go to school when the money is less'. ${ }^{112}$ The Rwandan media played a significant role by keeping education in the news and covering government, community and private sector efforts to increase access to education, to reduce gender disparities, and to create opportunities to recognise outstanding girls. ${ }^{113}$

In more recent years, women's CSOs have identified problems associated with menstruation and problems associated with pregnancy and childcare as the most pressing issues for students (Nock and Dusenge, 2012: 46-48). To address problems related to menstruation, every school has a budget to buy a few beds, buckets, basins and sanitary pads for girls to use when they are menstruating. This intervention reduces stigma and increases girls' attendance at school. ${ }^{114}$ In addition,

\footnotetext{
109 'Speeches', President Paul Kagame's website, http://www.paulkagame.com/index.php/speeches (accessed 17 December 2015). See, for example, speeches in 2015: http://paulkagame.com/?p=3932 (accessed 7 November 2017); 2010: http://paulkagame.com/?p=206 (accessed 7 November 2017); and 2009: http://paulkagame.com/?p=42 (accessed 7 November 2017).

${ }^{110}$ Interview with advisor, Ministry of Gender and Family Promotion, December 2014.

111 Interview with teacher, primary school, November 2014.

112 Interview with advisor, Ministry of Gender and Family Promotion, December 2014

113 Interview with lawyer and consultant, September 2014.

114 Interview with director, Roman Catholic primary school, December 2014; interview with director, private primary and secondary school in Kigali, December 2014; interview with advisor, Ministry of Gender and Family Promotion, December 2014.
} 
separation of boys' and girls' toilets has provided safety, security and freedom for girls at many schools. ${ }^{115}$

\section{Policy implications}

The achievement of gender parity in education in Rwanda underscores the influence of elite support in the Rwandan political settlement, as well as the impact of technocrats in the government administration. It also highlights the potential for international development policy, like the MDGs, to shape country-level development goals when there is sufficient buy-in from elites and the ruling party coalition. Rwanda's rapid progress and achievement of the MDGs for education and gender equality in education is remarkable, but these successes depend on selecting the most appropriate indicators for measuring progress and on ensuring that the numbers reported are accurate. For example, even though Rwanda has achieved the MDGs in terms of primary enrolment, some observers assert that UPE has led to a lower quality of education overall, because of overcrowded classrooms, high studentto-teacher ratios, and reduced contact hours due to the practice of 'double-shifting'. President Kagame is aware of these challenges, as he acknowledged them in a 2015 speech in Huye District. ${ }^{116}$ As discussed above, the leap in Rwanda's primary completion rates between 2008 and 2009 indicates this challenge. These completion rates appear to be attributed to the change in educational policy and the nine years (and now 12 years) of basic education for all. The long-term implications of this change in policy are unclear, as the quality of local secondary schools, which do not prepare students to continue on to tertiary education, has not been assessed as far as we have been able to ascertain. Nonetheless, when assessing Rwanda's educational achievements, the qualitative difference between primary completion and transition to secondary school rates between 2008 and 2009 must be taken into account.

\section{Conclusion: Reflections on adding gender analysis to the political settlement framework}

This paper set out to illuminate the ways that informal political institutions of the dominant party political settlement type affect the pursuit, adoption, implementation and outcomes of gender equity policies. We presented two policy cases: anti-GBV legislation, and gender equity in primary and secondary education, and shared some common developments between them. For both cases, it is clear that ideas about gender, promoting women's equality, and realising women's rights initially came from Rwandan women's CSOs and their leaders. Since at least the 1980s these women had been advocating vigorously for women's rights and making connections with an international women's rights movement. These women simultaneously called on indigenous Rwandan notions of gender complementarity (Burnet, 2008) and instruments of international law to demand change. Yet, these demands began to

\footnotetext{
${ }^{115}$ Interview with advisor, Ministry of Gender and Family Promotion, December 2014.

116 'President Kagame's speech in Huye District', 12 April 2015, http://paulkagame.com/?p=4104 (accessed 7 November 2017).
} 
have a greater impact and uptake following emergence of the current political settlement at the end of the 1994 genocide against the Tutsis.

Once the RPF became the dominant party, its prioritisation of gender equality within its ideological programme helped women's CSOs advocacy take root to change the status quo. Once women CSO leaders joined the government (and also the RPF, as noted above) in large numbers following the creation of gender quotas in 2003, attention to gender policies was further mainstreamed in the state institutions. In this way, the dominant party settlement type in Rwanda served to support adoption of gender-sensitive laws and policies and to accelerate their implementation. In addition, we found that the professional technocrats in the government administration and the system of performance contracts were key to Rwanda's success in implementing these policies that enhanced women's rights. These findings are significant, because previous studies identified the top-down political will and a vibrant women's movement as the most important factors related to adoption of the policies. While it is true that the vibrant women's movement and top-down political will initiated these changes, Rwanda also stands apart from many other countries in terms of its effective implementation of gender-sensitive laws and policies once they have been adopted. Several other important findings emerged from this case.

First, the Rwanda case in general, and these two policy cases in particular, call into question Htun and Weldon's (2010) typology of gender policies as either ameliorative or transformative. As noted above in the introduction, this typology is not always neatly applicable, since many policy initiatives are simultaneously ameliorative and transformative. Elsewhere, Burnet (2011) has argued that the accretion of an everincreasing set of gender policies and laws in Rwanda led to a transformation in normative ideas about women and gender equality that preceded the emergence of these to policy initiatives. Under Htun and Weldon's (2010) typology, Rwanda's antiGBV legislation would be classified as a transformative policy that altered fundamental notions of gender and challenged status quo interests of predominantly male powerbrokers within the political settlement. Gender equity in education, on the other hand, would be understood as an ameliorative policy in their typology, since it alleviates gender-based class inequities. A cursory analysis of Rwanda's adoption and implementation of anti-GBV legislation appears to uphold Htun and Weldon's typology. After extensive revision of the legislation passed, however, Nazneen and Masud's (2017) analysis of the 2010 Domestic Violence Act in Bangladesh demonstrates the ways that a 'transformative' policy's transformative power can be limited by lack of implementation. Taking into account their results, the anti-GBV law in the Rwanda case provides evidence for the ways that normative ideas about gender and women's equality had already changed before the law was adopted, rather than evidence of the transformative potential of the law itself. The educational reforms that led to gender equality in education fit more clearly into Htun and Weldon's typology, as these ameliorative policies gradually increased girls' access to primary and secondary education. Nonetheless, political elites have led awareness- 
raising campaigns to transform normative ideas surrounding girls' aptitudes for education and careers. ${ }^{117,118}$

Second, using the political settlement framework to trace the processes of genderinclusive policy initiatives yields some benefits in understanding the ways that both formal and informal political institutions affect outcomes of gender equity policies. This study highlighted the decisive role that political elites play in policy outcomes in dominant party type political settlements. For the anti-GBV law, the RPF's strong, ideological commitment to protecting women's rights helped to provide legitimacy to the political settlement. The ruling coalition's legitimacy was founded in its commitment to national unity and fighting genocide. Because GBV was imbricated in the long-term effects of the genocide, combatting it reinforced the dominant party's clear stance against genocide. Furthermore, the process to pass the law proceeded through formal channels, since potential sources of opposition were much weaker than the ruling coalition that was advocating for the legislation. The law was uncompromising in protecting women's rights, for the same reason. Where the law challenged patriarchal assumptions of male autonomy or dominance, advocates shifted the focus to align the legislation with protective forms of masculinity and male roles as fathers, sons or brothers instead of husbands.

Rwanda's political settlement was relatively stable during the period when anti-GBV legislation and gender parity in education were lobbied for, adopted and implemented. The dramatic earlier shift of the political settlement, which increased women's inclusion in governance and embedded women's rights in the dominant party's ideology, meant that advocates for these policies did not need to go outside of the ruling coalition to seek support for them. The president's strong commitment to gender equity meant that these policies faced far less contention that in other countries and led to a faster pace of adoption (Nazneen and Hickey, forthcoming, 2018).

Based on this case, however, we cannot contribute much to understanding how informal institutions influence political elites in dominant party political settlements when those elites either ignore the importance of, or outright oppose, enhancing women's rights. Analysis of the changes to Rwanda's maternity leave policies (a reduction in paid leave and expansion in unpaid leave in 2009 , with the passage of amendments to the labour code and the eventual restoration of this paid leave in 2015) would have been better suited to understanding these types of policies. ${ }^{119}$ The 2009 amendments to the labour code, which were promoted as improving the country's business climate for foreign investors, had strong support from President

\footnotetext{
${ }^{117}$ Interview with director, private primary and secondary school in Kigali, December 2014.

${ }^{118}$ See, for example, President Kagame's speech about girls' aptitudes for maths and science at the Commencement Ceremony for Gashora Girls' Academy for Science and Technology, Gashora, 4 October 2013, available at http://paulkagame.com/?p=2736 (accessed 7 November 2017).

${ }^{119}$ Law N 13/2009 of 27 May 2009.
} 
Kagame and the RPF leadership. It passed through parliament without any debate of the provisions to reduce paid maternity benefits, even though the legislature at the time was approximately 60 percent female. In 2015, these benefits were restored through a new law that restored the benefits as part of the social security administration benefit package. ${ }^{120}$ The change in law came after many years of sustained, behind-the-scenes (as opposed to public) lobbying by women's CSOs, women MPs and other women political elites wielding informal power.

Third, this study reveals the ways that transnational actors and discourses can influence the pursuit, adoption and outcomes of gender equity laws and policies in dominant party political settlements. Clearly, the MDGs helped to tip the balance in favour of mainstreaming gender equity in the Vision 2020 strategic plan, even though Rwandan women's CSOs had already effectively advocated for ameliorating women's rights in the aftermath of the 1994 genocide. The MCC Threshold grant from 2008 to 2011 may also have kept the Rwandan government's laser-like focus on meeting MDG goals wherever possible. This study, the political settlement framework, and publicly available data did not make it possible for us to analyse the ways in which international donors (i.e., bilateral aid organisations, UN funding, and other forms of international aid) directly impacted implementation or outcomes. For instance, we were able to identify some specific funding sources for projects related to these two policy initiatives, but we were unable to track overall changes in funding targeting the education sector from all sources during the period under study. Thus, the role of donors as actors in the political settlement framework, which is biased towards national-level analysis, remains to be determined. .

Finally, these two policy cases demonstrate the importance of Rwanda's accountability system and the professionalism and expertise of technocrats and femocrats in the government to Rwanda's success in implementing gender equity laws and policies. As Booth and Golooba-Mutebi found, in terms of understanding Rwanda as a 'developmental patrimonial state', the imihigo system has a robust effect because of 'the unusual level of backing, monitoring, and enforcement applied to it from the President's office downwards' (Booth and Golooba-Mutebi, 2012: 392 fn52). District mayors sign their performance contracts under authority of the president to serve the citizens of their district. ${ }^{121}$ When they do not meet their performance standards they are relieved of their duties, either because they resign or are because their contracts are terminated by the president. ${ }^{122}$ Chambers and Booth (2012: 3) report that the imihigo performance contract system also ensures accountability in the health care system because local officials' performance contracts include health indicators.

\footnotetext{
${ }^{120}$ Eugene Kwibuka, 'Full pay for maternity leave resumes in July', The New Times website, published 24 March 2015, http://www.newtimes.co.rw/section/article/2015-03-24/187192/ (accessed 30 December 2015).

121 'President Kagame presides over signing of 2014/2015 Imihigo', published 12 September 2014, http://paulkagame.com/?p=3632 (accessed 7 November 2015).

${ }^{122}$ Edwin Musoni, 'Behind resignation of district mayors', The New Times website, published 5 January 2015, http://www.newtimes.co.rw/section/article/2015-01-05/184662/ (accessed 31 December 2015).
} 


\section{References}

Acemoglu, D. Johnson, S. and Robinson, J. A. (2001). 'The colonial origins of comparative development: An empirical investigation', The American Economic Review, 91(5): 1369-1401.

Bernath, T. and Gahongayire, L. (2013). Final Evaluation of Rwandan Government and ISANGE One Stop Centre, New York: UN Women.

Berry, M. E. (2015). 'When "bright futures" fade: Paradoxes of women's empowerment in Rwanda', Signs, 41(1), 1-27.

Booth, D. and Golooba-Mutebi, F. (2012). 'Developmental patrimonialism? The case of Rwanda', African Affairs 111(444): 379-403.

Burnet, J. E. and RISD (2003). 'Culture, practice and law : Women's access to land in Rwanda', in L. M. Wanyeki (ed.), Women and Land in Africa : Culture, Religion and Realizing Women's Rights (New York: Zed Books), pp. 176206.

Burnet, J. E. (2008). 'Gender balance and the meanings of women in governance in post-genocide Rwanda', African Affairs, 107(428), 361-386.

Burnet, J. E. (2011). 'Women have found respect: Gender quotas, symbolic representation and female empowerment in Rwanda', Politics \& Gender, 7(3): 303-334.

Burnet, J. E. (2012). Genocide Lives in Us: Women, Memory, and Silence in Rwanda. Madison, Wl: University of Wisconsin Press.

Burnet, J. E. and Rwanda Initiative for Sustainable Development (2003). 'Culture, practice, and law: Women's access to land in Rwanda', in L. M. Wanyeki (ed.), Women and Land in Africa: Culture, Religion and Realizing Women's rights, New York: Zed Books.

Carpano, F. (2011). Strengthening Women's Access to Land in IFAD Projects: The Rwanda Experience. Rome: IFAD.

Chambers, V. and Booth, D. (2012). 'Delivering maternal health: Why is Rwanda doing better than Malawi, Niger and Uganda?', ODI Briefing Paper 74, London: Overseas Development Institute. Coffé, H. (2012). 'Conceptions of female political representation: Perspectives of Rwandan female representatives', Women's Studies International Forum, 35(4): 286-297. 
Dahlerup, D. (2005). 'Increasing women's political representation: New trends in gender quotas', in: J. Ballington and A. Karam (eds.), Women in Parliament: Beyond Numbers. Revised Edition, Berkley, CA: International Idea.

Devlin, C. and Elgie, R. (2008). 'The effect of increased women's representation in parliament: The case of Rwanda', Parliamentary Affairs, 61(2): 237-54.

Di John, J. and Putzel, J. (2009). 'Political settlements', GSDRC Issues Paper, University of Birmingham.

FPR Inkotanyi (2008). RPF Constitution, http://rpfinkotanyi.org/wp/?page id=97 (accessed 3 February 2014).

Fritz, V. and Menocal, A. R. (2007). 'Developmental states in the new millennium: Concepts and challenges for a new aid agenda', Development Policy Review, 25(5), 531-552.

Golooba-Mutebi, F. (2013). 'Politics, political settlements and social change in postcolonial Rwanda', ESID Working Paper 24. Manchester: Effective States and Inclusive Development Research Centre, The University of Manchester.

Gready P. (2010). "YYou're either with us or against us”: Civil society and policy making in post-genocide Rwanda', African Affairs, 109: 637-57.

Great Lakes Voice (2013). 'NEC releases preliminary MP candidates list', online article, available at: http://greatlakesvoice.com/nec-releases-preliminary-mpcandidates-list/ (accessed 7 November 2017). Kigali: Great Lakes Voice

Hoben, S. J. (1989). School, Work, and Equity: Educational Reform in Rwanda (Vol. 16). Boston, MA: African Studies Center, Boston University.

Hodari, J. (2014). 'The Isange One Stop Centre: A holistic approach to sexual and gender-based violence', The Police Chief, 81: 40-43.

Htun, M. and Weldon, S. L. (2010). 'When do governments promote women's rights? A framework for the comparative analysis of sex equality policy', Perspectives on Politics, 8(1).

Human Rights Watch (HRW) (1996). Shattered Lives: Sexual Violence During the Rwandan Genocide and its Aftermath. New York: HRW.

International Crisis Group (2002). Rwanda at the End of the Transition: A Necessary Political Liberalisation. Brussels/Nairobi: International Crisis Group.

Jefremovas, V. (2002). Brickyards to Graveyards: From Production to Genocide in Rwanda, Albany, NY: State University of New York Press. 
Kawamara-Mishambi, S. and Ovonji-Odida, I. (2003). 'The "lost clause": The campaign to advance women's property rights in the Uganda 1998 Land Act', in A. M. Goetzand S. Hassim (eds.), No Shortcuts to Power: African Women in Politics and Policy Making. London: Zed Books.

Khan, M. (2004). 'State failure in developing countries and institutional reform strategies', in B. Tungodden, N. Stern and I. Kolstad (eds.), Toward Pro-Poor Policies. Aid, Institutions, and Globalization. Annual World Bank Conference on Development Economics, Europe (2003). Oxford: Oxford University and World Bank.

Khan, M. (2010). 'Political settlements and the governance of growth-enhancing institutions'. Monograph. London: SOAS.

King, E. (2013). From Classroom to Conflict in Rwanda. Cambridge: Cambridge University Press.

Kwibuka, E. (2015). 'Full pay for maternity leave resumes in July', The New Times, 24 March. Available online: http://www.newtimes.co.rw/section/article/201503-24/187192/ (accessed 7 November 2017).

Laws, E. (2012). 'Political settlements, elite pacts and governments of national unity: A conceptual study', Background Paper 10. Birmingham: Developmental Leadership Program.

Levy, B. (2012). Working with the Grain: Integrating Governance and Growth in Development Strategies. Oxford: Oxford University Press.

Longman T. (1997). 'Rwanda: Democratization and disorder - Political transformation and social deterioration', in J. F. Clark and D. E. Gardinier (eds.), Political Reform in Francophone Africa. Boulder, CO: Westview Press.

Longman, T. (2006). 'Rwanda: Achieving equality or serving an authoritarian state?' In H. E. Britton and G. Bauer (eds.), Women in African Parliaments, Boulder, CO: Lynne Rienner Publishers.

Longman T. (2011). 'Limitations to political reform: The undemocratic nature of transition in Rwanda', in S. Straus and L. Waldorf (eds.), Remaking Rwanda: State Building and Human Rights after Mass Violence, Madison, WI: University of Wisconsin Press.

Mageza- Barthel, R. (2015). Mobilizing Transnational Gender Politics in Postgenocide Rwanda. Abingdon: Routledge. 
Mannell, G. and Jackson, S. (2014). 'Intimate partner violence in Rwanda: Women's voices'. London: London School of Economics. Available at: http://eprints.Ise.ac.uk/60014/ (accessed 7 November 2017).

Mills, G. and Wiesemes, R. (2012). 'Educating Minorities and Developing Community Cohesion in Post-Genocide Rwanda', in C. Atkin (ed.), Education and Minorities, London: Continuum.

Ministry of Education (MINEDUC) (2003). Education Sector Policy. Kigali: Ministry of Education (MINEDUC).

Ministry of Gender and Family Promotion (MIGEPROF) (2011). National Policy against Gender-Based Violence. Kigali: Ministry of Gender and Family Promotion (MIGEPROF).

Ministry of Local Government, Communal Development, and Social Affairs (MINALOC) (2004). Dénombrement des victimes du génocide. Kigali: Ministry of Local Government, Communal Development, and Social Affairs (MINALOC).

Ministry of Planning (MINIPLAN) (1986). Note explicative sur le projets des grandes orientations du IVème plan. April 28. Kigali: Ministry of Planning (MINIPLAN).

Nazneen, S. (2012). 'Research note on gender and political settlement'. Unpublished mimeo. Manchester: Effective Staes and Inclusive Development Research Centre.

Nazneen, S. and Hickey, S. (forthcoming, 2018). 'Political settlements and gender: What drives women's political inclusion and gender equity initiatives?' ESID Working Paper. Manchester: Effective States and Inclusive Development Research Centre.

Nazneen, S. and Mahmud, S. (2012). 'Gendered Politics of Securing Inclusive Development', ESID Working Paper No. 13, University of Manchester.

Nazneen, S. and Masud, R. (2017). 'The politics of promoting gender equity in Bangladesh', ESID Working Paper 76. Manchester: Effective States and Inclusive Development Research Centre, The University of Manchester.

Newbury, C. and Baldwin, H. (2001). 'Confronting the aftermath of conflict: Women's organizations in postgenocide Rwanda', in K. Kumar (ed.), Women and Civil War: Impact, Organizations, and Action. Boulder, CO: Lynne Rienner.

Nock, S. and Dusenge, A. (2012). Gender Equality in Teaching and Education Management: A participatory qualitative research report by Pro-femmes 
Twese Hamwe and VSO Rwanda. Kigali, Rwanda: Pro-femmes Twese Hamwe and VSO Rwanda.

North, D. (1990). Institutions, Institutional Change and Economic Performance, Cambridge: Cambridge University Press.

North, D., Wallis, J. J. and Weingast, B. R. (2009). Violence and Social Orders: A Conceptual Framework for Interpreting Recorded Human History, Cambridge: Cambridge University Press.

Overseas Development Institute (ODI) (2009). Sector Budget Support in Practice Rwanda Education Case Study. London: ODI.

Powley, E. (2005). 'Rwanda: Women hold up half the parliament', in J. Ballington and A. Karam (eds.), Women in Parliament: Beyond Numbers. A Revised Edition. Stockholm: International Institute for Democracy and Electoral Assistance.

Powley, E. and Pearson, E. (2007). "Gender is society": Inclusive lawmaking in Rwanda's parliament', Critical Half (Winter).

Republic of Rwanda (1999). 'Law No 22/99 of 12/11/99 to supplement book one of the civil code and to institute part five regarding matrimonial regimes, liberalities and successions'. Official Gazette of the Republic of Rwanda, 38(22).

Republic of Rwanda (2000). Rwanda Vision 2020. Kigali: Ministry of Finance and Economic Planning.

Republic of Rwanda (2010). National Gender Policy. Kigali: Ministry of Gender and Family Promotion.

Republic of Rwanda (2009). 'Law No 13/2009 of 27/05/2009 regulating labour in Rwanda.

Reyntjens, F. (1985). Pouvoir et droit au Rwanda: Droit public et évolution politique, 1916-1973, Tervuren: Musée Royal de l'Afrique Centrale.

Rwandan News Agency (2015). 'Rwandan Isange One Stop model to tackle gender based violence', 5 November. Kigali: Rwandan News Agency.

Samset, I. and Dalby, O. (2003). 'Rwanda: Presidential and parliamentary elections 2003', in G. Kval (ed.), NORDEM Report 12. Oslo: The Norwegian Institute of Human Rights/NORDEM.

Simons, J. D. and Schultze, C. (eds.) (2011). Impact of the Land Reform on the Land Rights and Economic Poverty Reduction of the Majority Rural, Especially 
Political settlements, women's representation and gender equality: The 2008 gender-based violence law and gender parity in primary and secondary education in Rwanda

Women Who Depend on Land for their Livelihood: Rwanda Case Study. Kigali: Rwanda Initiative for Sustainable Development/IS-Academie.

Thomson, D. R., Assiatou, B. B., Rubanzana, W. G. and Mutesa, L. (2015). 'Correlates of intimate partner violence against women during a time of rapid social transition in Rwanda: Analysis of the 2005 and 2010 Demographic and Health Surveys'. BMC Women's Health 15(1):1-13.

UNESCO (2014). Teaching and Learning: Achieving Quality for All, EFA Global Monitoring Report, Paris: UNESCO.

United Nations Population Fund (UNFPA) and Government of Rwanda (GOR) (n.d.). Country Assessment on Violence against Women - Rwanda.

United States Department of Labor's Bureau of International Labor Affairs (ILAB) (2013). Rwanda 2013 Findings on the Worst Forms of Child Labor, Washington, DC: ILAB. 


\section{Annex 1. Interviewee characteristics}

Table 5. Interviewee demographics

\begin{tabular}{|lc|}
\hline Sex & \\
\hline Male & 10 \\
\hline Female & 25 \\
\hline Education Level & \\
\hline Secondary school & 1 \\
\hline Bachelor's degree & 14 \\
\hline Graduate degree & 9 \\
\hline Did not ask / missing & 11 \\
\hline
\end{tabular}

Table 6. Current position by type

\begin{tabular}{|c|c|}
\hline Position Type & \\
\hline Citizen or employed in private sector & 7 \\
\hline $\begin{array}{l}\text { Representative or employee, civil society } \\
\text { organisation }\end{array}$ & 8 \\
\hline Educator & 6 \\
\hline $\begin{array}{l}\text { Representative or employee, international NGO or } \\
\text { UN }\end{array}$ & 2 \\
\hline Legislator or other elected official & 3 \\
\hline Representative, National Police & 1 \\
\hline
\end{tabular}

\section{List of interviewees by current or former position}

1. Staff member, UN Women; member, Réseau des Femmes

2. Former minister, Ministry of Gender and Family Promotion

3. Member of parliament

4. Director, Roman Catholic secondary school; former member, National Education Board

5. Executive secretary, women's civil society organisation; member, Réseau des Femmes

6. Education expert and consultant

7. Lawyer and consultant; former executive secretary, Haguruka

8. Representative, Rwanda Men's Resource Center (RWAMREC); member, Rwandan Civil Society Platform

9. Representative, Gender Monitoring Office

10. Representative, National Women Council

11. Member of parliament and representative, Forum of Women Parliamentarians (FWP)

12. Representative, Transparency International-Rwanda; civil society leader

13. Consultant and expert on gender

14. Director, Ministry of Gender and Family Promotion

15. Consultant and expert on gender-based violence; member, Réseau des Femmes

16. Former staff member, Collectifs des Associations Féminines de la Région des Grands Lacs (COCAFEM)

17. Director, primary school 
Political settlements, women's representation and gender equality: The 2008 gender-based violence law and gender parity in primary and secondary education in Rwanda

18. Representative, Transparency International-Rwanda

19. Programme manager, Pro-Femmes Twese Hamwe

20. Representative, Forum of African Women Educators in Rwanda

21. Director, Ministry of Education

22. Consultant and expert on gender; former director, Gender Monitoring Office

23. Representative, First Lady's Office

24. Women's civil society activist

25. Teacher, primary school

26. Advisor, Ministry of Gender and Family Promotion

27. National GBV advisor, international NGO, Kigali, Rwanda

28. Director, Roman Catholic primary school

29. Director, private primary and secondary school in Kigali

30. Journalist

31. Programme director, Rwanda Women Network

32. Senior officer, National Police

33. GBV officer, Ministry of Health

34. Statistician, Ministry of Education

35. Parent and citizen 


\section{Annex 2. Interview guide}

Study title: Gender and political settlement: A comparative analysis of gendered inclusion and policy influence in developing countries (Rwanda case)

Investigators' names and addresses:

Jennie E. Burnet, Associate Professor,

Department of Anthropology,

University of Louisville,

Louisville, KY 40292, USA.

Jeanne d'Arc Kanakuze, Independent Consultant,

Nyanza, Gatenga Kicukiro.

Email: jeannecap@yahoo.fr

Sites where study is to be conducted: Kigali, Rwanda

Phone number for subjects to call for questions: In Rwanda +250 788-510-206 or +250 789-175-813. In USA: +1 502-852-2424

Interview format: Semi-structured

After the purposes of the research have been explained and the informed consent procedure has been completed, the interviewer will begin the interview by asking general questions about women's rights, gender parity and the Rwandan political landscape. Not all topics will be covered with all interviewees. Not all questions will be asked of all interviewees.

List of topics to be covered and sample questions:

\section{Biographical information}

Tell me about yourself.

- How old are you? What year were you born?

- Where were you born?

- Where did you grow up?

- What is your marital status? Single/married/divorced/widowed

- Where did you go to school? What grade level did you stop studying?

- What is your profession?

\section{History of women's movement in Rwanda}

Questions in this section will be tailored to the interviewee's knowledge of or role in the women's movement. For example, whether the interviewee is a government functionary, parliamentarian, representative of a women's civil society organisation, representative of a political party, male ally of the women's movement, etc. 
Tell me about the women's movement in Rwanda and its achievements to date.

- What state institutions, political parties or civil society organisations have been key actors in the history of the Rwandan women's movement?

- What have been the successes or positive changes achieved by the Rwandan women's movement?

- What challenges has the Rwandan women's movement faced in its struggle for women's rights?

o Has anyone resisted or opposed the changes related to women's rights?

- What reasons did they give for their opposition?

- How did the women's movement respond to this opposition and the reasons given?

- What have been the critical junctures or key moments for the Rwandan women's movement?

0 Is there anything else?

o After the person says, 'there is nothing else', then use the following as probes:

- What about the 1994 genocide against Tutsis?

- What about the drafting of the genocide law in 1995 and moving rape from category 2 to category 1 ?

- What about the inheritance law?

- What about the constitutional commission, constitutional drafting process, and national consultation?

- What about the 2013 parliamentary elections, where women won 63 percent of the seats in the Chamber of Deputies?

- What strategies is the Rwandan women's movement using to ensure its gains/successes do not slip away?

\section{Gender parity in education}

Tell me about the initiative to achieve gender parity in education.

- When did this policy issue first emerge in Rwanda?

- Who were the key actors (specific people, offices or institutions) involved in making gender parity in education a priority in Rwanda?

o In government?

o In civil society?

o In the media?

o In parliament?

o In the Ministry of Education?

o In the Ministry of Gender and Family Promotion?

o In the National Women's Council or women's councils at other levels of government? 
o In the Rwandan Patriotic Front?

o In the other political parties?

o In the churches?

o In private schools?

o Among business leaders?

- Among the key actors you mentioned, did any of them form a coalition?

0 Around what issues specifically?

- Did anyone resist or oppose actions to decrease the gender gap in education?

o What reasons did they give for their opposition?

o How did the key actors involved respond to this opposition and the reasons given?

- Have the reforms been effectively implemented?

o If yes, what explains this successful implementation?

o What changed in terms of capacity and commitment?

- What are the key achievements regarding gender parity in education to date?

o Have there been any unintended effects?

- Were there any international organisations; initiatives; conferences or meetings; or treaties, conventions or other legal instruments that influenced gender parity in education emerging as a priority?

0 If yes, what were they?

o What about the Millennium Development Goals?

- What are the next steps in reinforcing gender parity in primary education?

- What are the next steps in achieving gender parity at the secondary and tertiary levels?

- What are your recommendations for the next steps?

\section{Gender-based violence (GBV) law and policy}

Tell me about the initiative to create the gender-based violence law and policy.

- When did this policy issue first emerge in Rwanda?

- Who were the key actors (specific people, offices or institutions) involved in making GBV a legal and policy priority in Rwanda?

o In government?

o In civil society?

o In parliament?

o In the Ministry of Gender and Family Promotion?

o In the National Women's Council or women's councils at other levels of government?

o In the Rwandan Patriotic Front?

o In the other political parties?

- Among the key actors you mentioned, did any of them form a coalition?

o Around what issues specifically?

- Who drafted the first GBV bill introduced in parliament in 2006? 
- Were there any international organisations; initiatives; conferences or meetings; or treaties, conventions or other legal instruments that influenced gender-based violence emerging as a priority?

o If yes, what were they?

- Did anyone resist or oppose all or parts (for example, particular articles) of the GBV law?

o What reasons did they give for their opposition?

o How did the key actors involved respond to this opposition and the reasons given?

- How did the consultation process on the GBV law proceed?

o Who initiated the consultation process?

o What were the key outcomes of the consultation process?

- What or whose interests and needs were considered in finalising the GBV law?

- What are the key achievements regarding GBV to date?

- How is the GBV law being implemented?

o Who are the key actors involved in implementing the GBV law and policy?

- In the national government?

- In the provincial governments?

- In the district governments?

- In other levels of government administration?

- In the National Police?

- In the Ministry of Gender and Family Promotion?

- In civil society?

- In the Rwandan Patriotic Front?

- In the other political parties?

o What obstacles (if any) are preventing the full implementation of this law? Which specific actors, institutions or ideas?

- What are the next steps in reinforcing the achievements regarding GBV in Rwanda?

- How has the GBV law drafting process, grassroots consultation and finalisation of the law affected Rwandan political institutions?

o Which institutions has it strengthened?

o What were the challenges encountered during the process?

- What are your recommendations for continued implementation of the GBV law?

\section{Individual involvement in women's movement and identified policy areas}

- Do you consider yourself to be part of the Rwandan women's movement?

Question to be asked of interviewees who DO NOT self-identify as members of the Rwandan women's movement:

o Why not? 
Political settlements, women's representation and gender equality: The 2008 gender-based violence law and gender parity in primary and secondary education in Rwanda

Questions to be asked of interviewees who DO self-identify as members of the Rwandan women's movement:

- When did you join the Rwandan women's movement?

- Where did you learn about women's rights? Who first told you about women's rights? Feminism? The Rwandan women's movement?

- Why did you join the Rwandan women's movement?

o Did you lose anything socially, economically or politically when you joined?

o Did you gain anything socially, economically or politically when you joined?

- Do you belong to a Rwandan women's association?

o If yes, which ones?

o How long have you been a member of

o Have you held a leadership position in

- How often do you participate in a meeting, conference or other event related to the Rwandan women's movement? 


\section{Annex 3. Key documents, policies and laws examined}

Abbott, P., Homans, H., Rugira, L. and Rwirahira, J. (2011). UNFPA Rwanda $6^{\text {th }}$ Country Programme End of Line Evaluation, Centre for Sustainable International Development, UK, and Institute of Policy Analysis and Research, Rwanda.

Ballington, J. and Karam, A. (eds.) (2005). Women in Parliament: Beyond Numbers.

A Revised Edition. Stockholm: Institute for Democracy and Electoral Assistance.

CEDAW (2009). Concluding Observations of the Committee on the Elimination of Discrimination against Women: Rwanda, C/RWA/CO/6.

CEDAW (2015). Consideration of Reports Submitted by States Parties Under Article 18 of the Convention, C/RWA/7-9 Rwanda.

DFID (2010). 'Building peaceful states and socities', DFID Practice Paper. London: UKAID.

Horvath, E., Zukani, M., Eppel, D., Kays, M., Konare, A., Park, Y., Pischalnikova, E., Stankard, N. and Zingher, T. (2007). Gender-based Violence Laws in SubSaharan Africa. Report prepared for the Committee on African Affairs of the New York City Bar as part of a pro bono project coordinated by The Cyrus R. Vance Center for International Justice. New York.

Millennium Challenge Account Threshold Program Assistance Agreement (2008). Millennium Challenge Account Threshold Program Assistance Agreement Between the United States of America and the Government of the Republic of Rwanda to Strengthen Political Rights, Civil Liberties and Voice and Accountability. USAID/Rwanda Assistance Agreement No. 696-AG-696MCC-X7-08-00001.

MINALOC (2004). Rwanda Five-Year Decentralisation Implementation Programme. Kigali: Ministry of Local Government, Community Development and Social Affairs.

MINALOC (2011). Decentralization Implementation Plan (DIP) 2011-2015.

MINEDUC (2008). Girls' Education Policy.

MINEDUC (2008). Higher Education Policy.

MINEDUC (2008). Nine Years Basic Education Implementaition: Fast Track Strategies.

MINEDUC (2010). Appraisal: Education Sector Strategic Plan (ESSP) 2010-2015.

MINEDUC (2012). Rwanda Education Statistics. Kigali.

MINEDUC (2013). 2012 Education Statistics Yearbook. Kigali.

MINEDUC (n.d.). Education Sector Strategic Plan 2008-2012.

Minister in the Prime Minister's Office in Charge of Family and Gender Promotion (2007). Single Report Equal to Fourth, Fifth and Sixth Reports on the Implementation of the Convention on the Elimination of all Forms of Discrimination Against Women Period: 1994-2005.

Ministry of Education, Science, Technology and Scientific Research (2003). Education Sector Policy. Kigali.

Ministry of Gender and Family Promotion (2010). National Gender Policy: Final Version. 
Ministry of Gender and Family Promotion (2011). National Policy against GenderBased Violence.

Ministry of Gender and Family Promotion (2011). National Strategic Plan for Fighting Against Gender-Based Violence 2011-2016.

Mugabe, A., Dusabumuremyi, E. and Rwego, A. (2012). Gender-based Violence (GBV) Base-Line Study in 13 Districts, RWAMREC/RWN/AJEPRODHO, Kigali.

National Electoral Commission (2013). Fact Sheet: Rwandan Parliamentary Elections 16 September 2013.

National Institute of Statistics of Rwanda (n.d.). EICV3 Thematic Report Education, Kigali.

Official Gazette of the Republic of Rwanda (1999). Summary, Law/n $22 / 99$ of 12/11/1999.

Official Gazette of the Republic of Rwanda (2005). Summary, $\mathrm{N}^{\circ} 08 / 2005$ of 14/07/2005.

Official Gazette of the Republic of Rwanda (2007). Summary, N $N^{\circ} 51 / 2007$ of 20/09/2007.

Official Gazette of the Republic of Rwanda (2009). Summary, N59/2008of 10/09/2008.

Official Gazette of the Republic of Rwanda (2009). Summary, $N^{\circ} 13 / 2009$ of 27/05/2009.

Overseas Development Institute (ODI) (2009). Sector Budget Support in Practice: Case Study Education Sector in Rwanda. London.

Pro-Femmes Twese Hamwe. Key Statistics on Gender Indicators.

Republic of Rwanda (2009). Country Report: Evaluation of the Implementation of the Beijing Declaration and Programme of Action. Kigali.

Republic of Rwanda (2009). National Evaluation Report on Implementation of the Beijing Declaration and Platform for Action (1995) and the Outcome of the Twenty-third Special Session of the General Assembly (2000). Kigali.

Republic of Rwanda (2010). National Action Plan 2009-2012, The United Nations Security Council Resolution 1325/2000 on Women, Peace and Security.

Republic of Rwanda, United Nations Rwanda, and UNFPA (n.d.). Country Assessment on Violence against Women. Rwanda.

Transparency Rwanda (n.d.). Gender Based Corruption in Workplaces in Rwanda. Kigali.

US Labor Report (2008). Rwanda.

US Labor Report (2012). Rwanda, 2011 Findings on the Worst Forms of Child Labor, United States Department of Labor's Bureau of International Labor Affairs.

US Labor Report (2013). Rwanda: Minimal Advancement, 2013 Findings on the Worst Forms of Child Labor, United States Department of Labor's Bureau of International Labor Affairs.

World Bank Database. Education Data for Rwanda. 1985-2013. 


\section{esid}

\section{The Effective States and Inclusive Development Research Centre}

The Effective States and Inclusive Development Research Centre (ESID) aims to improve the use of governance research evidence in decision-making. Our key focus is on the role of state effectiveness and elite commitment in achieving inclusive development and social justice.

ESID is a partnership of highly reputed research and policy institutes based in Africa, Asia, Europe and North America. The lead institution is the University of Manchester.

The other institutional partners are:

- $\quad$ BRAC Institute of Governance and Development, BRAC University, Dhaka

- $\quad$ Center for Democratic Development, Accra

- $\quad$ Center for International Development, Harvard University, Boston

- Department of Political and Administrative Studies, University of Malawi, Zomba

- $\quad$ Graduate School of Development, Policy \& Practice, Cape Town University

- Institute for Economic Growth, Delhi

In addition to its institutional partners, ESID has established a network of leading research collaborators and policy/uptake experts. 